\title{
Abnormal germinal center reactions in systemic lupus erythematosus demonstrated by blockade of CD154-CD40 interactions
}

\author{
Amrie C. Grammer, ${ }^{1}$ Rebecca Slota, ${ }^{1}$ Randy Fischer, ${ }^{1}$ Hanan Gur,${ }^{1}$ Hermann Girschick, ${ }^{1}$ \\ Cheryl Yarboro, ${ }^{2}$ Gabor G. Illei, ${ }^{2}$ and Peter E. Lipsky ${ }^{1,2,3}$ \\ ${ }^{1}$ Autoimmunity Branch and \\ ${ }^{2}$ Office of the Clinical Director, \\ ${ }^{3}$ Intramural Research Program, National Institute of Arthritis and Musculoskeletal and Skin Diseases, NIH, \\ Department of Health and Human Services, Bethesda, Maryland, USA
}

To determine the role of CD154-CD40 interactions in the B cell overactivity exhibited by patients with active systemic lupus erythematosus (SLE), $\mathrm{CD} 19^{+}$peripheral B cells were examined before and after treatment with humanized anti-CD154 mAb (BG9588, 5c8). Before treatment, SLE patients manifested activated B cells that expressed CD154, CD69, CD38, CD5, and CD27. Cells expressing CD38, CD5, or CD27 disappeared from the periphery during treatment with anti-CD154 mAb, and cells expressing CD69 and CD154 disappeared from the periphery during the post-treatment period. Before treatment, active-SLE patients had circulating CD38 ${ }^{\text {bright }}$ Ig-secreting cells that were not found in normal individuals. Disappearance of this plasma cell subset during treatment was associated with decreases in anti-double-stranded DNA (anti-dsDNA) Ab levels, proteinuria, and SLE disease activity index. Consistent with this finding, peripheral B cells cultured in vitro spontaneously proliferated and secreted Ig in a manner that was inhibited by anti-CD154 mAb. Finally, the CD38 ${ }^{+/+} \mathrm{IgD}^{+}$, $\mathrm{CD}^{2+++}$, and $\mathrm{CD}^{2} 8^{+} \mathrm{IgD}^{-} \mathrm{B}$ cell subsets present in the peripheral blood also disappeared following treatment with humanized anti-CD154. Together, these results indicate that patients with active lupus nephritis exhibit abnormalities in the peripheral B cell compartment that are consistent with intensive germinal center activity, are driven via CD154-CD40 interactions, and may reflect or contribute to the propensity of these patients to produce autoantibodies.

J. Clin. Invest. 112:1506-1520 (2003). doi:10.1172/JCI200319301.

\section{Introduction}

Systemic lupus erythematosus (SLE) is a chronic autoimmune disease characterized by the production of multiple autoantibodies and by $B$ cell hyperactivity that may either reflect intrinsic abnormalities or result from immunoregulatory defects in other cell types (1-4). Intrinsic or extrinsic perturbations of B cell maturation may permit generation, activation, differentiation, and clonal expansion of $B$ cells that secrete pathogenic autoantibodies. Maturation of $\mathrm{Ab}$ responses

Received for publication June 24, 2003, and accepted in revised form September 30, 2003.

Address correspondence to: Amrie C. Grammer, B Cell Biology Group Leader, Autoimmunity Branch, National Institute of Arthritis and Musculoskeletal and Skin Diseases, NIH, 9000 Rockville Pike, Building 10, Room 6D47A, Bethesda, Maryland 20892, USA. Phone: (301) 594-3493; Fax: (301) 402-2209;

E-mail: grammera@mail.nih.gov;

Website: http://www.irp.niams.nih.gov.

Conflict of interest: The authors have declared that no conflict of interest exists.

Nonstandard abbreviations used: systemic lupus erythematosus (SLE); germinal center (GC); double-stranded DNA (dsDNA); phycoerythrin (PE); tricolor (TC; PE-Cychrome 5);

intracytoplasmic (IC); mean fluorescence intensity (MFI); SLE disease activity index (SLEDAI). occurs within germinal centers (GCs). Following activation in an antigen- and MHC-restricted manner, CD154-expressing $\mathrm{T}$ cells initiate the $\mathrm{GC}$ reaction by engaging $\mathrm{CD} 40$-expressing pre-switch $\mathrm{IgD}^{+}$or postswitch $\mathrm{IgD}^{-} \mathrm{B}$ cells, thereby inducing them to express early-activation markers (CD69 and CD154) and differentiation markers (CD38, CD5, and CD27) (5-10) and to proliferate rapidly to form $\mathrm{IgD}^{+}$primary or $\mathrm{IgD}^{-}$ secondary follicles, more commonly referred to as GCs (11). Previous studies have defined functional B cell subsets from inflamed secondary lymphoid tissue, such as tonsil (12-21), or the periphery of active-SLE patients (22-29) by expression of CD27 and CD5, as well as $\mathrm{IgD}$ and CD38. Specifically, B cells that are bright for $\mathrm{CD} 38, \mathrm{CD} 27$, or $\mathrm{CD} 5$ have been shown to be Ig-secreting plasma cells, and cells expressing a low level of CD38, CD27, or CD5 have been shown to be memory-cell intermediates in the differentiation pathway to Ig-secreting plasma cells. Homotypic CD154CD $40 \mathrm{~B}$ cell interactions are essential for maintenance of ongoing GC reactions as well as for the differentiation of intermediates in the pathway to Ig-secreting plasma cells, such as from GCs to memory cells and from reactivated memory cells to Ig-secreting plasma cells $(5,30-38)$. The observation that $\mathrm{T}$ and $\mathrm{B}$ cells in 
the periphery of active-SLE patients spontaneously express CD154 suggests that GCs are abnormally releasing activated lymphocytes into the periphery, implying overactivity of GC reactions. Blocking CD154-CD40 interactions in vivo with humanized anti-CD154 (BG9588, 5c8) mAb in active-SLE patients may, therefore, interfere with the induction and maintenance of these ongoing GC reactions that produce autoantigen-specific memory and Ig-secreting plasma cells. The purpose of this study was to determine whether blocking CD154-CD40 interactions in vivo with a humanized mAb to CD154 (BG9588, 5c8) would interfere with the abnormal $\mathrm{B}$ cell activation in patients with active SLE and would also ameliorate signs and symptoms of the disease.

\section{Methods}

Patients and clinical data. The design of the clinical trial, including selection and exclusion of patients as well as preparation and administration of the humanized antiCD154 mAb (BG9588, 5c8; Biogen Inc., Cambridge, Massachusetts, USA) and clinical monitoring, has been described $(39,40)$. Briefly, BG9588 consists of the complementarity-determining regions of the murine antihuman $\mathrm{CD} 154 \mathrm{mAb} 5 \mathrm{c} 8$, combined with human variable-region and framework-region residues and IgG1 and $\kappa$ heavy and light chains, respectively. It was infused at a concentration of $20 \mathrm{mg} / \mathrm{kg}$ at weeks $0,2,4$, 8 , and 12 (Table 1). Patients receiving hydroxychloroquine were allowed to continue their therapy during the treatment period at a constant level (Table 1). Prednisone was tapered according to a predetermined schedule during the treatment period, beginning 1 month after the first dose of humanized anti-CD154 $\mathrm{mAb}(\mathrm{BG} 9588,5 \mathrm{c} 8)(40)$. The trial was prematurely terminated because of an increased frequency of thromboembolic events in patients in centers outside of the
NIH. A total of six patients were treated at the Clinical Center of the NIH. This report describes four patients who received three or more infusions of humanized anti-CD154 mAb (BG9588, 5c8). All four female patients described in this article (age $34 \pm 7$ years, range 25-45 years) fulfilled the American College of Rheumatology criteria (41), had active lupus nephritis for 2.7-8 years before entry into the trial with mean proteinuria levels of $3.2 \pm 1.4 \mathrm{~g} / 24 \mathrm{~h}$ (range 1.7-4.9 g/ $24 \mathrm{~h}$ ), and were positive for anti-double-stranded DNA (anti-dsDNA) Ab (188.5 $\pm 355.0 \mathrm{IU} / \mathrm{ml}$, range 9.4-981.0 $\mathrm{IU} / \mathrm{ml}$, normal value $<3.6 \mathrm{IU} / \mathrm{ml})$. Active nephritis was defined as a renal biopsy showing proliferative lupus nephritis within 5 years before the first dose of humanized anti-CD154 mAb (BG9588, 5c8), proteinuria of at least $1.0 \mathrm{~g} / \mathrm{d}$ at two separate screening visits, and any one of the following four criteria at each of the two screening visits: (a) anti-dsDNA Ab greater than twice the upper limit of normal (normal value $<3.6 \mathrm{IU} / \mathrm{ml}$ ); (b) complement protein 3 (C3) less than $80 \mathrm{mg} / \mathrm{dl}$; (c) hematuria greater than 5 rbc's per high-power field; and (d) granular or rbc casts detected on urine analysis. Patient characteristics, concomitant treatment, and anti-CD154 schedules of treatment and assessment are summarized in Table 1.

Cell preparation and purification. PBMCs were obtained from non-autoimmune, healthy normal volunteers $(n=8)$ by centrifugation of collected heparinized blood over diatrizoate/Ficoll gradients (Sigma-Aldrich, St. Louis, Missouri, USA). PBMCs from the four activeSLE patients were obtained following collection of peripheral blood in vacutainer citrated cell-preparation tubes (Becton Dickinson, San Jose, California, USA) according to the manufacturer's instructions. Tonsillar mononuclear cells $(n=5-22)$ were obtained as described previously (5). Briefly, tonsils were minced and digested in RPMI containing $210 \mathrm{U} / \mathrm{ml}$ collagenase

Table 1

Patient characteristics

\begin{tabular}{|c|c|c|c|c|c|c|c|}
\hline Patient & Ethnicity & $\begin{array}{l}\text { Disease/ } \\
\text { Nephritis } \\
\text { duration } \\
(y r)\end{array}$ & $\begin{array}{l}\text { Clinical } \\
\text { involvement }\end{array}$ & $\begin{array}{c}\text { SLEDAl/ } \\
\text { Anti-DNA } \\
(\mathrm{IU} / \mathrm{ml}) / \text { Proteinuria } \\
(\mathrm{g} / 24 \mathrm{~h})\end{array}$ & $\begin{array}{l}\text { Concomitant } \\
\text { treatment }\end{array}$ & $\begin{array}{l}\text { Anti-CD154 } \\
\text { treatment } \\
\text { schedule }\end{array}$ & $\begin{array}{l}\text { Anti-CD154 } \\
\text { assessment } \\
\text { schedule }\end{array}$ \\
\hline $1(45 \mathrm{yr}, \mathrm{F})$ & Caucasian & $8 / 8$ & $\begin{array}{l}\text { Type IV GN, arthritis, } \\
\text { malar rash, hematologic }\end{array}$ & $12 / 23.9 / 4.85$ & $\begin{array}{l}\text { Prednisone } \\
25 \mathrm{mg} \text { qd }\end{array}$ & $\begin{array}{c}0,2,4,8,12 \\
\text { weeks }\end{array}$ & $\begin{array}{l}0,2,4,8,12,16 \\
\text { weeks plus } 3 \\
\text { and } 20 \text { months } \\
\text { after final treatment }\end{array}$ \\
\hline $2(31 \mathrm{yr}, \mathrm{F})$ & Caucasian & $9 / 7$ & $\begin{array}{l}\text { Type III GN, arthritis, } \\
\text { malar rash }\end{array}$ & $8 / 31.6 / 1.67$ & $\begin{array}{l}\text { Prednisone } \\
5 \mathrm{mg} \text { qd, HCLQ } \\
400 \mathrm{mg} \text { qd }\end{array}$ & $\begin{array}{l}0,2,4,8 \\
\text { weeks }\end{array}$ & $\begin{array}{l}0,2,4,8,12 \\
\text { weeks plus } 20 \\
\text { months after } \\
\text { final treatment }\end{array}$ \\
\hline $3(25 \mathrm{yr}, \mathrm{F})$ & African-American & $8 / 7.5$ & $\begin{array}{l}\text { Type IV GN, arthritis, } \\
\text { rash, pericarditis }\end{array}$ & $8 / 9.4 / 4.42$ & $\begin{array}{l}\text { Prednisone } \\
20 \text { mg qd, } \\
\text { HCLQ } \\
400 \mathrm{mg} \mathrm{qd}\end{array}$ & $\begin{array}{l}0,2,4,8 \\
\text { weeks }\end{array}$ & $\begin{array}{l}0,2,4,8,12 \\
\text { weeks plus } \\
2 \text { months after } \\
\text { final treatment }\end{array}$ \\
\hline $4(35 \mathrm{yr}, \mathrm{F})$ & Asian & $5 / 2.7$ & $\begin{array}{l}\text { Type IV GN, arthritis, } \\
\text { malar rash, pleuritis, } \\
\text { subacute cutaneous LE, } \\
\text { photosensitivity }\end{array}$ & $18 / 981 / 1.85$ & $\begin{array}{l}\text { Prednisone } \\
30 \text { mg qd, } \\
\text { HCLQ } \\
400 \mathrm{mg} \text { qd }\end{array}$ & $\begin{array}{l}0,2,4 \\
\text { weeks }\end{array}$ & $\begin{array}{l}0,2,4 \text { weeks } \\
\text { plus } 20 \text { months } \\
\text { after final treatment }\end{array}$ \\
\hline
\end{tabular}

F, female; GN, glomerulonephritis; LE, lupus erythematosus; qd, four times a day; HCLQ, hydroxychloroquine. 
type I (Worthington Biochemical Corp., Lakewood, New Jersey, USA) and $90 \mathrm{U} / \mathrm{ml}$ DNase (Sigma-Aldrich) for 30 minutes at $37^{\circ} \mathrm{C}$. Following filtration through a wire mesh, the cells were washed twice in $20 \%$ FBS/RPMI and once in 10\% FBS-RPMI before centrifugation over diatrizoate/Ficoll gradients.

In some cases, B cells were negatively selected on a magnetic column (StemCell Technologies, Vancouver, British Columbia, Canada) after staining with a mixture of dextran cross-linked mAb specific for glycophorin A, CD2, CD3, CD14, CD16, CD33, and CD56, followed by exposure to a magnetic colloid covalently linked to anti-dextran mAb. The resultant population of B cells was analyzed by flow cytometry and found to be more than $97 \%$ positive for sIg (FITC-conjugated anti-polyvalent Ig Ab; Caltag, Burlingame, California, USA). Alternatively, PBMCs were stained with phycoerythrin-conjugated (PE-conjugated) anti-CD19 (Becton Dickinson, San Jose, California, USA) and sorted for the $\mathrm{CD} 19^{+}$population using the FACSVantage SE (Becton Dickinson).

Analysis of $B$ cell function. B cells were cultured $\left(1 \times 10^{5}\right.$ per well) in U-bottom microtiter plates (Costar-Corning Inc., Corning, New York, USA) in RPMI (Life Technologies Inc., Grand Island, New York, USA) supplemented with penicillin $\mathrm{G}(200 \mathrm{U} / \mathrm{ml})$, gentamicin $(10 \mu \mathrm{g} / \mathrm{ml})$, and $10 \%$ FCS. For analysis of the effects of CD154, cells were incubated in the presence of a previously described saturating concentration of $10 \mu \mathrm{g} / \mathrm{ml}$ (5) of the mouse anti-CD154 mAb (5c8; a kind gift from Biogen Inc.) or an isotype-matched control $\mathrm{Ab}$ (P1.17; mouse IgG2a; American Type Culture Collection, Manassas, Virginia, USA). In some cases, the humanized mouse antihuman $\mathrm{CD} 154 \mathrm{mAb}$ used in the clinical trial, or pooled human Ig (Sandoglobulin; Novartis, East Hanover, New Jersey, USA) as a control, was used.

To measure proliferation as assessed by DNA synthesis, cells were incubated in duplicate for various periods at $37^{\circ} \mathrm{C}$ with $1 \mu \mathrm{Ci}\left[{ }^{3} \mathrm{H}\right] \mathrm{TdR}$ present for the last 18 hours of culture. Cells were harvested onto glass filter paper, and $\left[{ }^{3} \mathrm{H}\right] \mathrm{TdR}$ incorporation was determined by liquid scintillation spectroscopy.

$\operatorname{IgM}$ and IgG from pooled supernatants were analyzed by ELISA. Polystyrene microtiter plates were coated with capture $\mathrm{Ab}$ by incubation overnight at $37^{\circ} \mathrm{C}$. After washing and blocking, coated plates were incubated with serial dilutions of standards or appropriately diluted culture supernatants for 16 hours at $37^{\circ} \mathrm{C}$. Washed plates were incubated with peroxidaseconjugated goat anti-human IgM or IgG Ab for 1-2 hours at $37^{\circ} \mathrm{C}$. After addition of substrate (o-phenylenediamine or chlorophenolred- $\beta$-D-galactopyranoside), the development of colored reaction product was quantitated using an ELISA reader.

Flow cytometric analysis. For analysis of activationantigen expression, PBMCs were stained with FITCconjugated anti-IgD (Caltag Laboratories Inc.), TriColor (TC; PE-Cychrome 5)-conjugated anti-CD19 (Caltag Laboratories Inc.), APC-conjugated anti-CD38
(Becton Dickinson), and PE-conjugated $\mathrm{mAb}$ against CD69 (Becton Dickinson) or CD154 (89-76; Becton Dickinson) as previously described (5). In some cases, CD154 was identified by staining with unconjugated anti-CD154 (5c8; Biogen Inc.) followed by PE-conjugated goat anti-mouse Ig as previously described (5). Alternatively, PBMCs were stained with a combination of FITC-conjugated anti-IgD, PE-conjugated antiCD19 (Becton Dickinson), and TC-conjugated antiCD5 (Caltag Laboratories Inc.); a combination of FITC-conjugated anti-CD27 (Becton Dickinson), PEconjugated anti-IgD (Pharmingen), and TC-conjugated anti-CD19; or a combination of FITC-conjugated anti-IgD, PE-conjugated anti-IgM, and TC-conjugated anti-CD19. Cells were stained with $\mathrm{mAb}$ according to the manufacturer's instructions in PBS with $1 \%$ BSA at $4^{\circ} \mathrm{C}$ for 30 minutes. Cells were washed and resuspended in PBS with $1 \%$ BSA before analysis with FACSCalibur (Becton Dickinson). PAINT-A-GATE and CellQuest (Becton Dickinson) were used to analyze data generated by flow cytometry.

To determine the presence of Ig-secreting plasma cells and the cell cycle status of B cells, cells were fixed and permeabilized with FACSjuice or fixed with FACSlyse (Becton Dickinson) for 10 minutes in the dark at room temperature, washed with $1 \% \mathrm{BSA} / \mathrm{PBS}$, and stained with FITC-conjugated goat $\mathrm{F}\left(\mathrm{ab}^{\prime}\right)_{2}$ antihuman Ig or IgD (Caltag) and APC-conjugated antiCD38 mAb. Cells were incubated with hypotonic propidium iodide solution to identify the presence of apoptotic cells and cells in cycle. The percentage of cells that were positive for intracytoplasmic (IC) Ig and the mean fluorescence intensity (MFI) of IC Ig expression were determined using the CellQuest and PAINTA-GATE programs (Becton Dickinson). Specifically, IC Ig expression was determined by subtraction of the histogram representing the combination of surface and IC Ig expression in permeabilized cells.

$P C R$ analysis of $C D 154 \mathrm{mRNA}$. CD19+ $\mathrm{B}$ cells were sorted from PBMCs stained with fluorochrome-conjugated anti-CD19 into 96-well PCR plates (Robbins Scientific Corp., Sunnyvale, California, USA) using a FACSVantage flow cytometer (Becton Dickinson). Total RNA was extracted using the RNeasy RNA isolation kit (QIAGEN Inc., Chatsworth, California, USA). From each patient, $0.1 \times 10^{6}$ sorted $\mathrm{B}$ cells were used for RNA preparation. Contaminating genomic DNA was removed using RQ1 RNase-free DNase (Promega Corp., Madison, Wisconsin, USA) according to the manufacturer's instructions. For conversion of mRNA into cDNA, SuperScript II Reverse Transcriptase (Life Technologies Inc.) was used according to the manufacturer's instructions. The following sequences of oligonucleotides were used as primers for the amplification of cDNA: CD154 sense, $5^{\prime}$-AGTCAGGCCGTTGCTAGTCAGT-3'; CD154 antisense, 5'-GGAAACAATGGAGACTGCAGGTA-3'; CD154 nested sense, 5'AGTCAGGCCGTTGCTAGTCAGT-3'; CD154 nested antisense, $5^{\prime}$-TTATGAGGAGTGGGCAGGCTCAG-3'; CD40 sense, 5'-GCAGGCACAAACAAGACTGA-3'; CD40 anti- 
sense, 5'-CGACTCTCTTTGCCATCCTC-3'; CD40 nested sense, 5'-GCCAAGAAGCCAACCAATAA-3'; CD40 nested antisense, $5^{\prime}$-CGACTCTCTTTGCCATCCTC-3'; $\beta$-actin sense, $5^{\prime}$-GTCCTCTCCCAAGTCCACACA- $3^{\prime} ; \beta$-actin antisense, $5^{\prime}$-TGGTCTCAAGTCAGTGTACAGGTAA- $3^{\prime} ; \beta$-actin nested sense, $5^{\prime}$-GTCCTCTCCCAAGTCCACACA- $3^{\prime} ; \beta$-actin nested antisense, $5^{\prime}$-CTCAAGTTGGGGGACAAAAAG- ${ }^{\prime}$.

Statistics. Data are shown as the mean \pm SEM and were tested for statistical significance using the Student's $t$ test. Statistical significance in the figures and tables is indicated with pairs of symbols denoting specific comparisons.

\section{Results}

SLE B cells express functionally active CD154. Whereas T and $B$ cells from the periphery of normal, nonautoimmune volunteers were largely unactivated and CD154-negative, CD154 was spontaneously expressed on the surface of $B$ and $T$ cells from the periphery of active-SLE patients at similar densities (Figure 1a). Notably, in a separately analyzed active-SLE patient who was not part of the humanized anti-CD154 mAb treatment study, CD154 spontaneously expressed on the surface of active-SLE B cells was equivalently identified by the $5 \mathrm{c} 8$ clone of anti-CD154 (Biogen Inc.) or a commercially available anti-CD154 mAb (89-76; Becton Dickinson) (Figure 1b). Whereas highly purified $B$ cells from the periphery of normal, nonautoimmune volunteers did not proliferate or secrete Ig when cultured alone in vitro, cultured peripheral B cells from active-SLE patients spontaneously proliferated and secreted Ig in a manner that was inhibited significantly in the presence of a blocking anti-CD154 $\mathrm{mAb}$ (BG9588, 5c8) (Figure 1c).

Differences in expression of activation and differentiation antigens on $B$ cells from the periphery of active-SLE patients compared with B cells from the periphery or secondary lymphoid tissues of normal non-autoimmune volunteers. A number of activation and differentiation markers were assessed to determine the functional status of the SLE B cells in greater detail (Table 2). B cells in the blood of the active-SLE patients were activated as assessed by bright expression of IgM and spontaneous expression of CD69 and CD154 (Table 2). A significantly lower percentage of $B$ cells in the periphery of non-autoimmune normal volunteers spontaneously expressed these activation antigens. The percentages of active-SLE B cells expressing CD69 and CD154 as well as the densities of expression of CD69, CD154, and IgM were much higher on the pre-switch $\operatorname{IgD}{ }^{+}$ subset compared with the post-switch $\mathrm{IgD}^{-}$subset. This trend was also noted for peripheral B cells from normal non-autoimmune volunteers.

The percentage of $\mathrm{B}$ cells expressing CD27 or CD5 and the level of expression was significantly higher in pre-switch IgD ${ }^{+}$cells from active-SLE patients compared with cells from the periphery or the secondary lymphoid tissue tonsil of non-autoimmune volunteers (Table 2). In addition, the level of CD27 or CD5 expressed on post-switch $\operatorname{IgD}^{-} \mathrm{B}$ in the periphery of active-SLE patients was similar to that on cells from tonsil and was significantly higher than in the periphery of normal volunteers. Of interest, the percentage of post-switch $\mathrm{IgD}^{-} \mathrm{B}$ cells from active-SLE patients that expressed CD5 was significantly greater than that of cells from the periphery or the secondary lymphoid tissue tonsil of non-autoimmune normal volunteers. Moreover, there was no significant difference in the percentage of post-switch IgD- B cells expressing CD27 in the periphery of active-SLE patients compared with cells from the periphery or secondary lymphoid tissues of non-autoimmune volunteers.

The percentage of $\mathrm{B}$ cells expressing CD38 was significantly higher in pre-switch $\mathrm{IgD}^{+}$cells from activeSLE patients compared with cells from the periphery of normal non-autoimmune volunteers but was not significantly different from that in cells from the secondary lymphoid tissue tonsil (Table 2 ). In addition, the percentage of $\mathrm{B}$ cells expressing CD38 was significantly higher in pre-switch $\operatorname{IgD}^{+}$cells than in postswitch $\mathrm{IgD}^{-}$cells. Examples of B cell subsets defined by expression of CD38 and IgD are shown in Figure $2 \mathrm{a}$ for one tonsil that contained all eight possible subsets $(n=22)$, two different normal non-autoimmune volunteers $(n=8)$, and one active-SLE patient who exhibited all eight possible subsets. Notably, comparison of these subsets revealed that, on average, the percentage of $\mathrm{CD} 38^{+++} \mathrm{IgD}^{+}$Ig-secreting plasma cells was significantly higher $(P=0.035)$ in the peripheral blood of the SLE patients $(3.0 \% \pm 1.1 \%$, range $0-5 \%$ ) than in the non-autoimmune normal volunteers $(1.0 \% \pm 0.5 \%$, range $0-4 \%)$. Of interest, the percentage of $\mathrm{CD} 38^{+++} \mathrm{IgD}^{+}$plasma cells in the blood of active-SLE patients was comparable to the percentage found in the B cell compartment of chronically activated tonsil tissue $(3.0 \% \pm 1 \%$, range $0-8 \%)$. Moreover, there was a significantly higher percentage of $\mathrm{CD}_{38}{ }^{+} \mathrm{IgD}^{+} \mathrm{B}$ cells in the periphery of active-SLE patients $(35.3 \% \pm 4.5 \%$, range $24-45 \%)$ than in tonsil tissues $(17.0 \% \pm 3.8 \%$, range $1-33 \% ; P=0.0096)$, and there was a higher percentage of $\mathrm{CD} 38^{++} \mathrm{IgD}^{+} \mathrm{B}$ cells in the periphery of active-SLE patients $(16.5 \% \pm 6.1 \%$, range $5-28 \%)$ than in both blood $(4.5 \% \pm 1.0 \%$, range $0-8 \% ; P=0.01)$ and tonsil $(3.0 \% \pm 1.5 \%$, range $1-14 \%$; $P=0.0089$ ) from normal non-autoimmune volunteers. Furthermore, there was no significant difference between the percentages of CD38- $\operatorname{IgD}{ }^{+} \mathrm{B}$ cells in the periphery of non-autoimmune controls $(32.6 \% \pm 9.5 \%$, range $7.0-82.0 \%$ ) and active-SLE patients, but there was a significantly higher percentage of $C D 38-\operatorname{IgD}^{+} \mathrm{B}$ cells in the periphery of active-SLE patients $(21.8 \% \pm 1.2 \%$, range $20.0-25.0 \%)$ compared with the B cell compartment of tonsil tissue $(6.0 \% \pm 1.3 \%$, range $\left.1.0-13.0 \% ; P=9.6 \times 10^{-6}\right)$.

In contrast to the pre-switch $\operatorname{IgD}^{+}$peripheral B cell subsets as described above, there were no significant average differences in the post-switch $\operatorname{IgD}^{-}$peripheral $B$ cell subsets defined by CD38 in active-SLE 
Table 2

Phenotypic analysis of human B cell subsets

\begin{tabular}{|c|c|c|c|c|c|c|}
\hline & & $\mathrm{CD} 19^{+} \operatorname{IgD}^{+}$ & & & $\mathrm{CD}^{19^{+}} \mathrm{IgD}^{-}$ & \\
\hline & Normal PB $(n=8)$ & SLE PB $(n=4)$ & Tonsil $(n=5-22)$ & Normal PB & SLE PB & Tonsil \\
\hline $\lg M$ & & & & & & \\
\hline$\%$ & $\begin{array}{c}77.7 \pm 8.3^{x} \\
(61-86)\end{array}$ & $\begin{array}{c}95.5 \pm 4.2^{\mathrm{u}, \mathrm{x}} \\
(83-100)\end{array}$ & $\begin{array}{c}65.8 \pm 12.1^{\mathrm{f}, \mathrm{u}} \\
(33-91)\end{array}$ & $\begin{array}{c}17.7 \pm 6.7^{k} \\
(11-31)\end{array}$ & $\begin{array}{c}92.3 \pm 6.1^{\mathrm{b}, \mathrm{k}} \\
(74-100)\end{array}$ & $\begin{array}{c}23.0 \pm 11.9^{f, b} \\
(4-58)\end{array}$ \\
\hline MFI & $\begin{array}{c}60.0 \pm 12.3^{a} \\
(37-79)\end{array}$ & $\begin{array}{c}657.8 \pm 173.6^{\mathrm{a}, \mathrm{q}} \\
(157-952)\end{array}$ & $\begin{array}{c}136.0 \pm 38.79 \\
(47-236)\end{array}$ & $\begin{array}{c}21.7 \pm 5.2^{8} \\
(15-32)\end{array}$ & $\begin{array}{c}116.5 \pm 36.1 \\
(26-195)\end{array}$ & $\begin{array}{c}92.0 \pm 26.6^{8} \\
(35-162)\end{array}$ \\
\hline CD6s & & & & & & \\
\hline$\%$ & $\begin{array}{c}37.8 \pm 11.4 x \\
(3-92)\end{array}$ & $\begin{array}{c}70.5 \pm 12.0 \chi \\
(47-99)\end{array}$ & $\begin{array}{c}54.6 \pm 7.9 \\
(28-75)\end{array}$ & $\begin{array}{c}20.0 \pm 11.5 \\
(2-99)\end{array}$ & $\begin{array}{c}38.5 \pm 11.9 \\
(8-66)\end{array}$ & $\begin{array}{c}37.4 \pm 7.5 \\
(17-61)\end{array}$ \\
\hline MFI & $\begin{array}{c}172.6 \pm 57.1^{\delta} \\
(42-421)\end{array}$ & $\begin{array}{c}305.8 \pm 116.8 \mathrm{~g} \\
(84-579)\end{array}$ & $\begin{array}{c}58.8 \pm 13.99 \\
(7-90)\end{array}$ & $\begin{array}{c}38.3 \pm 3.1^{\mathrm{h}, \delta, \phi} \\
(28-52)\end{array}$ & $\begin{array}{c}78.3 \pm 27.1^{\phi} \\
(33-150)\end{array}$ & $\begin{array}{c}65.6 \pm 3.0^{h} \\
(56-72)\end{array}$ \\
\hline CD1 & & & & & & \\
\hline$\%$ & $\begin{array}{c}20.4 \pm 5.3^{\varphi} \\
(4-44)\end{array}$ & $\begin{array}{c}77.3 \pm 12.3^{\varphi, \pi, r} \\
(55-99)\end{array}$ & $\begin{array}{c}16.5 \pm 6.9^{r} \\
(3-49)\end{array}$ & $\begin{array}{c}6.1 \pm 3.8 \\
(0-31)\end{array}$ & $\begin{array}{c}17.0 \pm 7.5^{\pi} \\
(2-36)\end{array}$ & $\begin{array}{l}9.4 \pm 5.3 \\
(0.4-37)\end{array}$ \\
\hline MFI & $\begin{array}{c}930.8 \pm 281.3^{\lambda, v} \\
(175-2,521)\end{array}$ & $\begin{array}{c}1,054.3 \pm 244.4^{\mathrm{S}} \\
(559-1,553)\end{array}$ & $\begin{array}{c}284.5 \pm 167.0^{\mathrm{S}, \mathrm{v}} \\
(33-1,432)\end{array}$ & $\begin{array}{c}236.8 \pm 88.3^{\lambda, w} \\
\quad(0-705)\end{array}$ & $\begin{array}{c}1,264.3 \pm 517.6^{\mathrm{t}} \\
(169-2,969)\end{array}$ & $\begin{array}{l}53.5 \pm 17.4^{\mathrm{w}, \mathrm{t}} \\
\quad(20-138)\end{array}$ \\
\hline $\mathrm{CD} 27$ & & & & & & \\
\hline$\%$ & $\begin{array}{c}36.2 \pm 6.9^{9,13} \\
(19-62)\end{array}$ & $\begin{array}{c}97.0 \pm 2.1^{9, \mathrm{~m}} \\
(93-100)\end{array}$ & $\begin{array}{c}38.4 \pm 7.5^{\mathrm{j}, \mathrm{m}} \\
(24-62)\end{array}$ & $\begin{array}{c}66.7 \pm 7.7^{13} \\
(49-89)\end{array}$ & $\begin{array}{c}72.7 \pm 9.9 \\
(59-92)\end{array}$ & $\begin{array}{c}58.4 \pm 4.0^{j} \\
(45-67)\end{array}$ \\
\hline MFI & $\begin{array}{c}75.2 \pm 17.8^{11} \\
(29-142)\end{array}$ & $\begin{array}{c}467.3 \pm 157.0^{11, \mathrm{n}} \\
\quad(164-689)\end{array}$ & $\begin{array}{c}87.2 \pm 14.8^{n} \\
(39-130)\end{array}$ & $\begin{array}{c}39.8 \pm 6.0^{12, o} \\
(19-60)\end{array}$ & $\begin{array}{c}117.0 \pm 41.0^{12} \\
(39-178)\end{array}$ & $\begin{array}{c}76.0 \pm 19.1^{\circ} \\
(22-135)\end{array}$ \\
\hline CD5 & & & & & & \\
\hline$\%$ & $\begin{array}{c}51.3 \pm 8.8^{2} \\
(27-93)\end{array}$ & $\begin{array}{c}87.5 \pm 8.4^{2, c} \\
(64-100)\end{array}$ & $\begin{array}{c}45.1 \pm 13.3^{c} \\
(5-98)\end{array}$ & $\begin{array}{c}43.3 \pm 12.6^{3} \\
(6-94)\end{array}$ & $\begin{array}{c}85.0 \pm 11.6^{3, \mathrm{e}} \\
(51-100)\end{array}$ & $\begin{array}{l}36.4 \pm 15.6^{\mathrm{e}} \\
\quad(1-96)\end{array}$ \\
\hline MFI & $\begin{array}{c}528.3 \pm 130.3^{4,6} \\
(71-1,114)\end{array}$ & $\begin{array}{c}1,247.8 \pm 439.3^{4,7, d} \\
(371-2,464)\end{array}$ & $\begin{array}{c}276.3 \pm 102.7^{d} \\
(48-811)\end{array}$ & $\begin{array}{c}85.7 \pm 11.0^{5,6} \\
\quad(32-112)\end{array}$ & $\begin{array}{c}162.8 \pm 49.4^{5,7} \\
(94-306)\end{array}$ & $\begin{array}{c}200.9 \pm 95.2 \\
(29-760)\end{array}$ \\
\hline CD3s & & & & & & \\
\hline$\%$ & $\begin{array}{c}49.1 \pm 11.0 \\
(5-88)\end{array}$ & $\begin{array}{c}71.0 \pm 5.3^{\beta} \\
(57-81)\end{array}$ & $\begin{array}{c}73.6 \pm 4.0 \\
(5-90)\end{array}$ & $\begin{array}{c}45.0 \pm 9.6 \\
(4-72)\end{array}$ & $\begin{array}{c}51.8 \pm 3.7^{\beta} \\
(45-62)\end{array}$ & $\begin{array}{c}70.1 \pm 5.0 \\
(1-92)\end{array}$ \\
\hline MFI & $\begin{array}{c}139.0 \pm 25.0^{\alpha} \\
(42-208)\end{array}$ & $\begin{array}{c}412.5 \pm 200.2^{\alpha} \\
(187-1,012)\end{array}$ & $\begin{array}{c}259.7 \pm 84.8^{p} \\
(39-2,021)\end{array}$ & $\begin{array}{c}493.1 \pm 225.0 \\
(49-1,640)\end{array}$ & $\begin{array}{c}442.0 \pm 268.4 \\
(125-1,245)\end{array}$ & $\begin{array}{c}462.2 \pm 71.1 P \\
(30-1,739)\end{array}$ \\
\hline
\end{tabular}

Statistical significance $(P<0.05$; range $0.00003-0.049)$ is indicated with pairs of symbols denoting specific comparisons. Ranges are shown in parentheses. PB, peripheral blood.

patients compared with normal peripheral B cells. When compared with tonsil, the periphery of both active-SLE patients and normal non-autoimmune healthy volunteers had fewer $\mathrm{CD}^{+} 8^{+} \mathrm{IgD}^{-}$and $\mathrm{CD}^{2} 8^{++} \mathrm{IgD}^{-} \mathrm{B}$ cells.

Expression of differentiation and activation antigens during and after treatment of active-SLE patients with humanized anti-CD154 mAb (BG9588, 5c8). CD38 ${ }^{\text {positive }} \mathrm{B}$ cells in the circulation of the active-SLE patients disappeared from the peripheral blood during the treatment regimen with humanized anti-CD154 mAb (Figures 2b, 2c, and 3a). Specifically, before the treatment regimen, $65 \% \pm 5.5 \%$ of the $\mathrm{B}$ cells were $\mathrm{CD} 38$ positive . At 4-8 weeks after initiation of treatment, the percentage of CD38positive $\mathrm{B}$ cells in the circulation had dropped to $7.0 \% \pm 4.1 \%(P=0.00017$ compared with before treatment). Withdrawal of treatment led to a reappearance of $\mathrm{CD} 38$ positive $\mathrm{B}$ cells in the circulation $(73.8 \% \pm 6.9 \% ; P=0.00018)$ at the earliest time point tested, 2 months after treatment, at a percentage that was not different from the pretreatment percentage $(P>0.05)$. Of interest, this trend was significant for both the pre-switch $\mathrm{IgD}^{+}$and the postswitch $\operatorname{IgD}^{-} \mathrm{B}$ cell subsets.

Figures $2 \mathrm{~b}$ and $2 \mathrm{c}$ depict the effect of humanized anti-CD154 mAb treatment on the individual peripheral B cell subsets in active-SLE patients, defined by $\mathrm{CD} 38$ and $\mathrm{IgD}$. Four to eight weeks of treatment led to a significant reduction in the peripheral $\mathrm{CD} 38^{+/++} \mathrm{IgD}^{+}$ $\mathrm{B}$ cell and $\mathrm{CD}_{38^{+++}} \mathrm{IgD}^{+}$plasma cell populations and a significant mean increase in the $\mathrm{CD}^{2} 8^{-} \mathrm{IgD}^{-}$peripheral B cell population. After treatment was discontinued, these effects dissipated. Of note, the CD $38^{+++} \mathrm{IgD}^{-}$plasma cells that were present in the periphery of SLE patient no. 3 (SLE no. 3) disappeared from the periphery following two treatments with humanized anti-CD154. Interestingly, the CD38 $8^{+++}$ cells that reappeared in the circulation of SLE no. 3 two months after withdrawal of treatment were preswitch IgD ${ }^{+}$plasma cells (data not shown). 
By contrast, the percentage of $\mathrm{CD}^{2} 9^{+} \mathrm{B}$ cells observed in the periphery of SLE patients $(57.0 \% \pm 9.0 \%$, range 13.0-100.0\%; MFI 269.3 \pm 168.5 , range 59-633) did not significantly change during the treatment period (91.9\% $\pm 4.7 \%$, range $81-100 \%$; MFI $171 \pm 39.6$, range 101-279) but did decrease after the treatment was withdrawn $(62.3 \% \pm 7.3 \%$, range $46-79 \%$; MFI $305.8 \pm 134.7$, range 59-633; $P=0.011$ ) (Figure $3 \mathrm{~b}$ ). Separate analysis of the pre-switch $\mathrm{IgD}^{+}$and post-switch $\mathrm{IgD}^{-}$subsets revealed different trends of CD69 expression in response to treatment. Specifically, the pre-switch $\operatorname{IgD}^{+}$ subset followed the trend observed in the whole B cell population. By contrast, the percentage of $\mathrm{CD} 69^{+}$cells in the post-switch $\mathrm{IgD}^{-}$subset significantly increased following 4-8 weeks of treatment and then significantly decreased during the post-treatment period.

Similar to the disappearance of $\mathrm{CD} 69^{+} \mathrm{B}$ cells from the circulation following withdrawal of anti-CD154 treatment, the $\mathrm{CD}_{154^{+}}$pre-switch $\mathrm{IgD}^{+} \mathrm{B}$ cells observed in the periphery of SLE patients decreased after the treatment was stopped (Figure 4). Of note, CD154 protein expression on the surface of cells could not be examined during the time that antiCD154 mAb was being administered to the patients, since the treatment itself covered up available CD154 epitopes. For this reason, PCR analysis was used to monitor expression of CD154 mRNA in individually sorted CD19 ${ }^{+}$B cells at the pretreatment time point and after initiation of treatment. These experiments demonstrated that expression of CD154, and, as controls, $\beta$-actin and CD40, had not changed at 1 month after treatment initiation.

Figure 5 depicts the effect of humanized antiCD154 mAb treatment on the expression of CD27 on circulating peripheral B cells of individual active-SLE patients. Histograms of CD27 expression in normal non-autoimmune volunteers are shown for comparison. The percentage of pre-switch $\mathrm{IgD}^{+} \mathrm{B}$ cells expressing CD27 significantly decreased following treatment with anti-CD154 (pretreatment, $98.0 \% \pm 1.2 \%$, range 95-100\%; during treatment, $73.0 \% \pm 1.9 \%$, range 69-77\%; post-treatment, $43.0 \% \pm 22.2 \%$, range $13-97 \%$; $P=0.0004)$. There were no significant changes in CD27-expressing B cells in the post-switch $\mathrm{IgD}^{-}$subset. Individual patients exhibited different trends. For example, the percentage and MFI of CD27-expressing pre-switch $\mathrm{IgD}^{+}$cells in SLE nos. 1 and 2 continued to remain low in the post-treatment time period, whereas CD27-positive pre-switch $\mathrm{IgD}^{+}$cells reappeared in the periphery of SLE no. 3 following treatment withdrawal. These trends are reflected in the finding that, on average, pre-switch IgD+ cells expressing a low level of CD27 $\left(\mathrm{CD} 27^{\text {low } /+}\right)$ were significantly reduced $(P=0.0003)$ when comparing this population during treatment

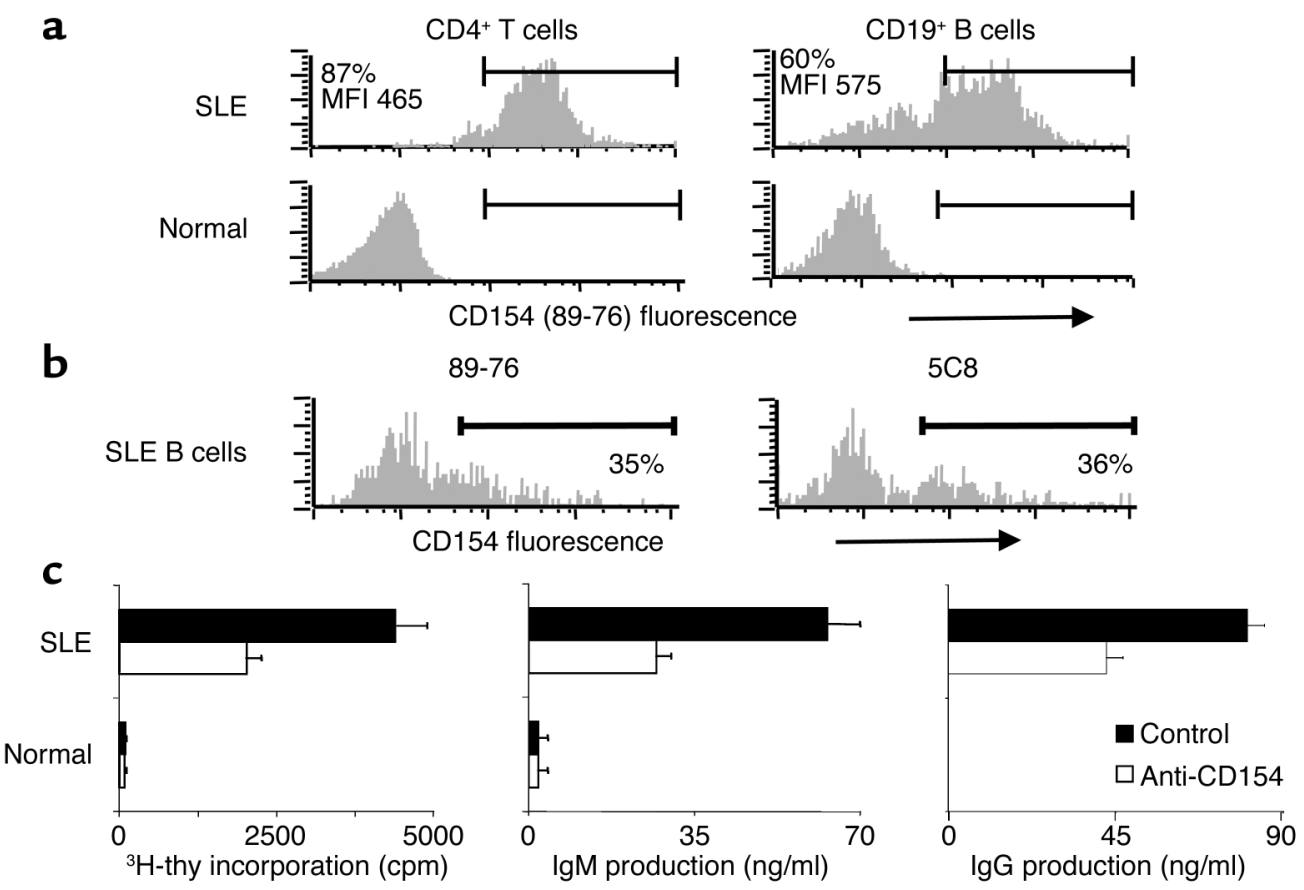

Figure 1

Freshly isolated SLE B cells express functionally active CD154. ( $\mathbf{a}$ and $\mathbf{b})$ CD154 expression on CD4 ${ }^{+} T$ cells and CD19+ $B$ cells from the periphery of SLE patients and normal volunteers was assessed by flow cytometric staining of PBMCs for CD154 (PE-conjugated 89-76; shown in $\mathbf{a}$ and in $\mathbf{b}$ [left panel]; unconjugated $5 \mathrm{c} 8$ followed by PE-conjugated goat anti-mouse Ig, $\mathbf{b}$ [right panel]) and CD19 or CD4 (APC-conjugated $\mathrm{mAb}, \mathbf{a}$ and $\mathbf{b})$. The results of two of six experiments with similar findings are shown. (c) Freshly isolated, negatively selected peripheral $B$ cells $\left(0.1 \times 10^{5}\right)$ from active-SLE patients and normal volunteers were incubated in the presence of $10 \mu \mathrm{g} / \mathrm{ml}$ anti-CD154 (mlgG2a; $5 \mathrm{c} 8$ ) or $10 \mu \mathrm{g} / \mathrm{ml}$ control Ab (mouse IgG2a; P1.17). Analysis of DNA synthesis was carried out on day 3. Ig production was analyzed by ELISA after a 5-day incubation. All determinations were performed in duplicate and are expressed as the mean $\pm \mathrm{SEM}$. The results of one of three experiments with similar findings are shown. ${ }^{3} \mathrm{H}$-thy, ${ }^{3} \mathrm{H}$-thymidine. 

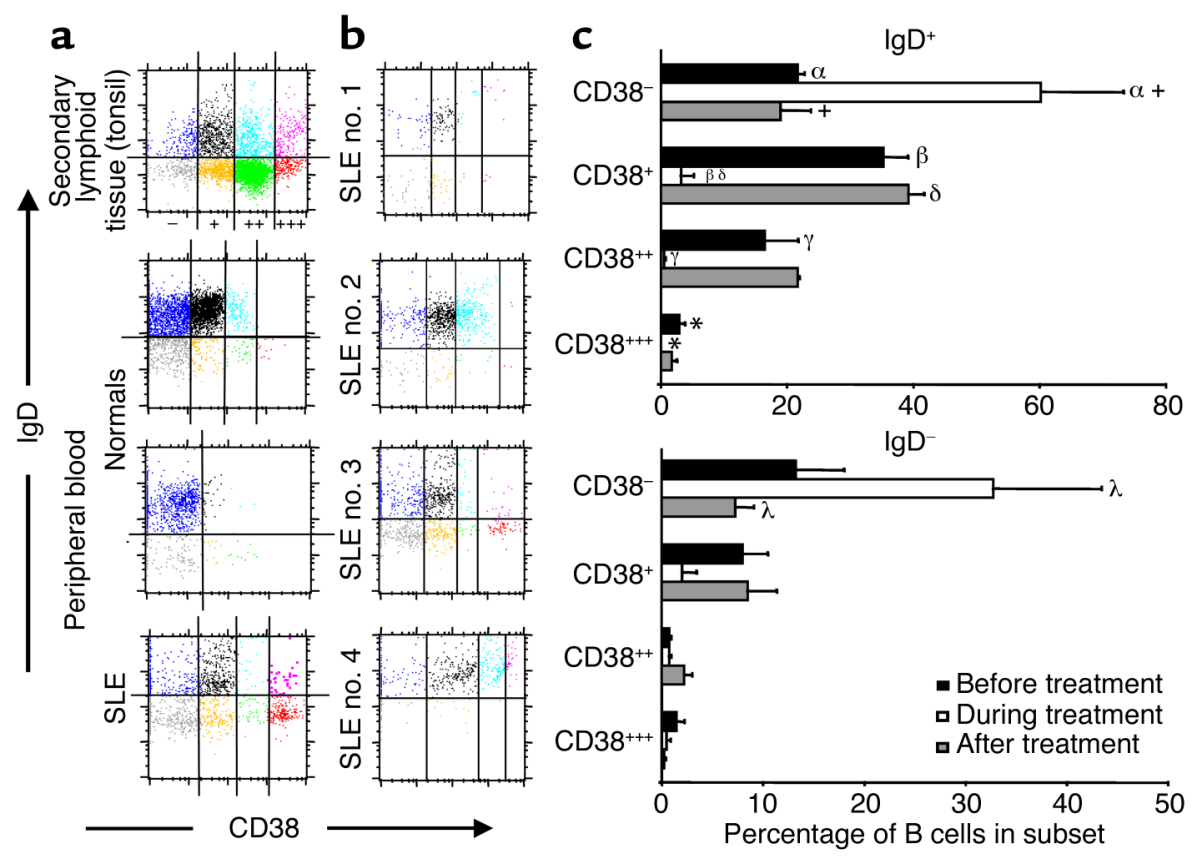

Figure 2

CD38-expressing B cell subsets in active-SLE blood disappear following two treatments with humanized anti-CD154 (5c8). Freshly isolated mononuclear cells (MNCs) from active-SLE patients ( $\mathbf{a}$ and $\mathbf{b}$ ), normal volunteers (a), and individual tonsils (a) were assessed for CD19+ subpopulations by FACS analysis following staining with FITC-conjugated anti-IgD, PE-conjugated anti-CD38, and APC-conjugated antiCD19. Freshly isolated PBMCs from active-SLE patients before treatment, during treatment (SLE nos. 1 and 2, 2 months; SLE nos. 3 and 4 , 1 month), and after treatment withdrawal (SLE no. 1, 3 months after; SLE no. 2, 20 months after; SLE no. 3, 2 months after; SLE no. 4, 20 months after) were assessed for $\mathrm{CD} 19^{+}$subpopulations by FACS analysis following staining with FITC-conjugated anti-lgD, PE-conjugated anti-CD38, and APC-conjugated anti-CD19 (c). The mean \pm SEM percentages of CD19+ B cells in each subset defined by CD38 and IgD are shown graphically. Statistical significance was determined by the Student's $t$ test and is depicted with each pair of symbols indicating a specific comparison: ${ }^{\lambda P}=0.0445,{ }^{\alpha} P=0.0208,{ }^{+} P=0.0208,{ }^{\beta} P=0.00037,{ }^{\delta} P=0.014, \gamma P=0.0197,{ }^{*} P=0.016$.

with the post-treatment time point (pretreatment, $38.3 \% \pm 18.4 \%$, range $13-74 \%$; during treatment, $50.3 \% \pm 5.2 \%$, range $40-56 \%$; post-treatment, $22.3 \% \pm$ $11.9 \%$, range $8-46 \%$ ). In addition, $\mathrm{CD} 27-\mathrm{IgD}^{+}$cells were significantly increased (pretreatment, $2.3 \% \pm 1.5 \%$, range $0-5$; during treatment, $27.3 \% \pm 2.3 \%$, range 23-31\%; post-treatment, $57.3 \% \pm 27.2 \%$, range $3-87 \%$ ) $(P=0.04)$ when comparing this population during treatment with the post-treatment time point.

Figure 6 depicts the effect of humanized anti-CD154 $\mathrm{mAb}$ treatment on the expression of CD5 on circulating peripheral B cells of active-SLE patients. Although no significant average differences were observed between the pre-switch $\operatorname{IgD}^{+}$and the post-switch $\mathrm{IgD}^{-}$ $B$ cell subsets in the percentage or density of total CD5 expression following treatment, there were significant differences within individual subsets. Notably, the preswitch cells that were bright for $\mathrm{CD} 5\left(\mathrm{CD}^{+++} \mathrm{IgD}^{+}\right)$significantly decreased $(P=0.02)$ in the periphery following 4-8 weeks of humanized anti-CD154 treatment (pretreatment, $18.3 \% \pm 3.4 \%$, range $14-25 \%$; during treatment, $7.7 \% \pm 1.8 \%$, range $5-11 \%$; post-treatment, $8.7 \% \pm 3.8 \%$, range $3-16 \%$ ). In addition, both preswitch $\mathrm{IgD}^{+}$and post-switch $\mathrm{IgD}^{-} \mathrm{B}$ cells expressing a low level of $\mathrm{CD} 5\left(\mathrm{CD}^{+}\right)$followed the same trend after humanized anti-CD154 treatment with respect to expression of CD69 and CD154. On average, the CD5 ${ }^{+}$ $\mathrm{B}$ cell subset did not change during the treatment period but significantly decreased $(P<0.04)$ following treatment withdrawal $\left(\mathrm{IgD}^{+}\right.$: pretreatment, $46.3 \% \pm$ $10.7 \%$, range $46-81 \%$; during treatment, $49.7 \% \pm 10.8 \%$, range $28-61 \%$; post-treatment, $11.7 \% \pm 3.3 \%$, range $5-16 \%$; IgD: : pretreatment, $65.6 \% \pm 10.3 \%$, range $46-81 \%$; during treatment, $62.0 \% \pm 12.1 \%$, range $38-76 \%$; post-treatment, $25.3 \% \pm 9.5 \%$, range $13-44 \%$ ). Different trends were noted in SLE nos. 2 and 3. Specifically, in SLE no. 2, the pre-switch $\operatorname{IgD}^{+}$and postswitch $\operatorname{IgD}^{-}$subsets that were positive for $\mathrm{CD} 5$ decreased in both percentage and MFI during treatment and after treatment withdrawal so that in the post-treatment period the pre-switch cells were mostly CD5-negative. In SLE no. 3, treatment with humanized anti-CD154 mAb decreased the density of CD5 on the surface of both pre-switch $\operatorname{IgD}^{+}$and post-switch $\mathrm{IgD}^{-} \mathrm{B}$ cells; this decrease was reversed in the posttreatment time period.

Treatment with humanized anti-CD154 mAb (BG9588, $5 c 8)$ has no effect on circulating lymphocyte numbers. Blocking CD154-CD40 interactions with humanized anti-CD154 mAb (BG9588, 5c8) did not significantly affect the total number of mononuclear cells, $\mathrm{CD}^{+}$ $\mathrm{T}$ cells, or $\mathrm{CD} 19^{+} \mathrm{B}$ cells found in the peripheral 

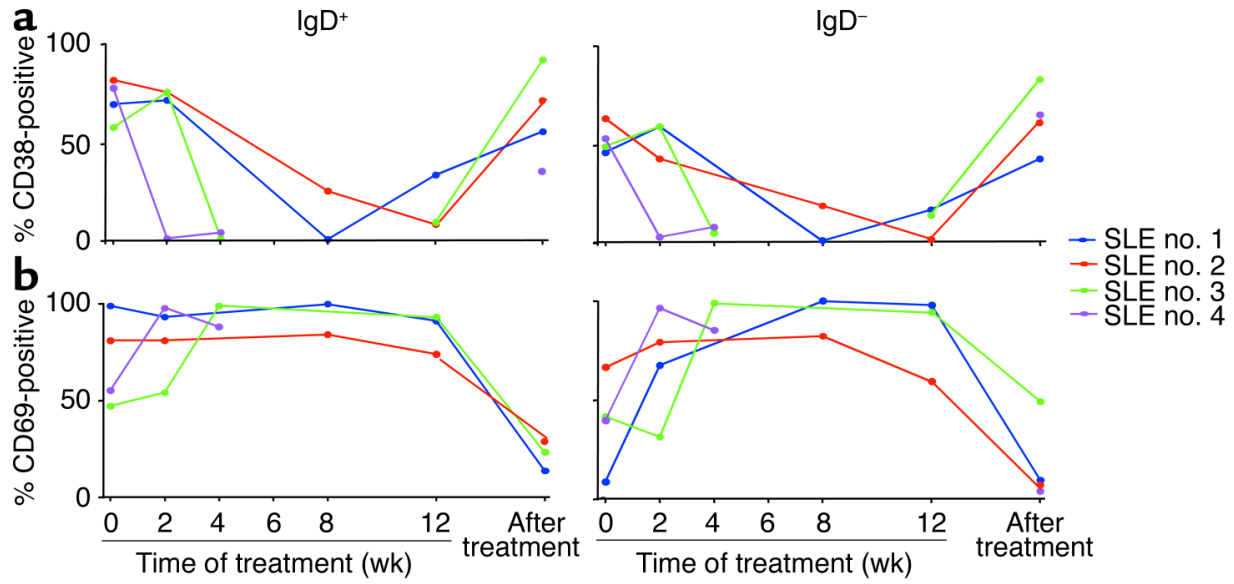

Figure 3

Expression of activation antigens by $B$ cells diminishes with different kinetics following treatment of active-SLE patients with humanized antiCD154 (5c8). Freshly isolated PBMCs from normal volunteers and active-SLE patients before treatment, during treatment, and after treatment (SLE no. 1, 2 months after; SLE no. 2, 20 months after; SLE no. 3, 3 months after; SLE no. 4, 20 months after) were assessed for CD69 and CD38 expression in CD19+ B cell subsets by FACS analysis following staining with FITC-conjugated anti-IgD, APC-conjugated anti-CD19, and $\mathrm{PE}$-conjugated $\mathrm{Ab}$ against $\mathrm{CD} 69$ or $\mathrm{CD} 38$. The percentages of $\mathrm{CD}_{19}{ }^{+}$pre-switch IgD ${ }^{+}$and post-switch IgD- B cells expressing CD38 (a) and CD69 (b) before, during, and after treatment are shown.

blood of these patients (40). Moreover, treatment of active SLE nephritis patients with humanized antiCD154 did not significantly change the ratio of preswitch $\operatorname{IgD}^{+}$to post-switch $\operatorname{IgD}^{-} \mathrm{B}$ cells in the periphery (before treatment, $6 \pm 3$, range $1-12 ; 2$ weeks after treatment initiation, $5 \pm 3$, range $1-13$; 1 month after treatment initiation, $3 \pm 2$, range $1-3 ; 2$ months after treatment initiation, $5 \pm 3$, range $1-6$; after final treatment, $2 \pm 1$, range $1-4 ; P>0.05$ ).

Spontaneously proliferating $B$ cells and Ig-secreting $B$ cells disappear from the peripheral blood of active-SLE patients following treatment with bumanized anti-CD154 mAb (BG9588, 5c8). A hallmark of active SLE is the presence of spontaneously proliferating $B$ cells in the periphery (Figure 1c). For SLE patient nos. 1 and 2 who participated in the anti-CD154 mAb trial, spontaneously proliferating $B$ cells were observed in the periphery as assessed by the percentage of peripheral $\mathrm{B}$ cells in the $\mathrm{S} / \mathrm{G}_{2} / \mathrm{M}$ stages of the cell cycle (Figure $7 \mathrm{a}$ ). Two treatments with humanized anti-CD154 mAb decreased the presence of these cells in the circulation, but they reappeared in the circulation following withdrawal of treatment. Of note, B cells in the periphery of non-

\section{Figure 4}

CD154 expression by active-SLE B cells after a treatment course with humanized anti-CD154 (5c8). Individual CD19+ $\mathrm{B}$ cells in freshly isolated PBMCs from normal volunteers and active-SLE patients before treatment, after two treatments, and 2-3 months after treatment were identified following staining with fluorochrome-conjugated anti-CD19 and either sorted into individual wells using a FACSVantage flow cytometer (a) or additionally stained with PE-conjugated anti-CD154 (89-76; b). Transcripts of CD154, CD40, and $\beta$-actin mRNA were identified by PCR and Southern blotting (a). Surface expression of CD154 is shown in $\mathbf{b}$, where the dotted line indicates the cutoff for staining with a PE-conjugated isotype-matched control Ab. autoimmune normal volunteers do not spontaneously proliferate (Figure $1 \mathrm{c}$ ) and thus are in the $\mathrm{G}_{0}$ or $\mathrm{G}_{1}$ stage of the cell cycle (data not shown).

Circulating Ig-secreting cells were identified in the blood of two of four of the SLE patients (nos. 1 and 3). Whereas less than $1 \%$ of the PBMCs isolated from SLE no. 1 were positive for IC Ig (data not shown), $3 \%$ of the PBMCs isolated from SLE no. 3 were positive for IC $\mathrm{Ig}$ (Figure 7b). As expected, all of these cells were CD38 $8^{\text {bright }(+++)}$. Interestingly, $60 \%$ of the $\mathrm{IC} \mathrm{Ig}^{+}$cells were in the $\mathrm{S}, \mathrm{G}_{2}$, or $\mathrm{M}$ phase of the cell cycle, indicating that they were dividing plasma cells, whereas the remaining $40 \%$ were in the $\mathrm{G}_{0}$ or $\mathrm{G}_{1}$ phase, representing nonproliferating plasma cells. Treatment of SLE no. 3 with humanized anti-CD154 mAb resulted in complete and

a

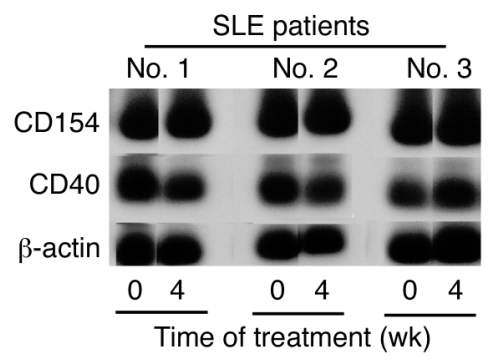

b $\lg \mathrm{D}^{+}$

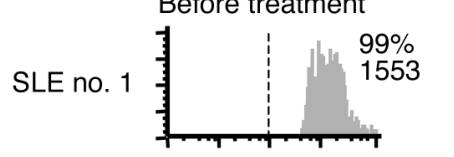
After treatment

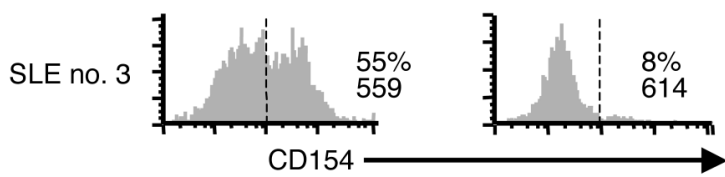




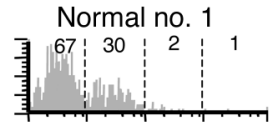

SLE no. 1
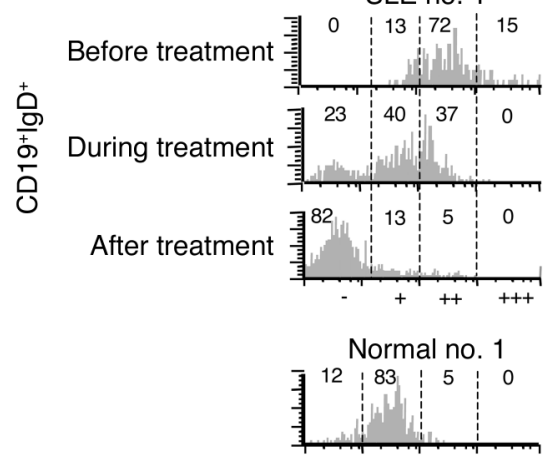

SLE no. 1

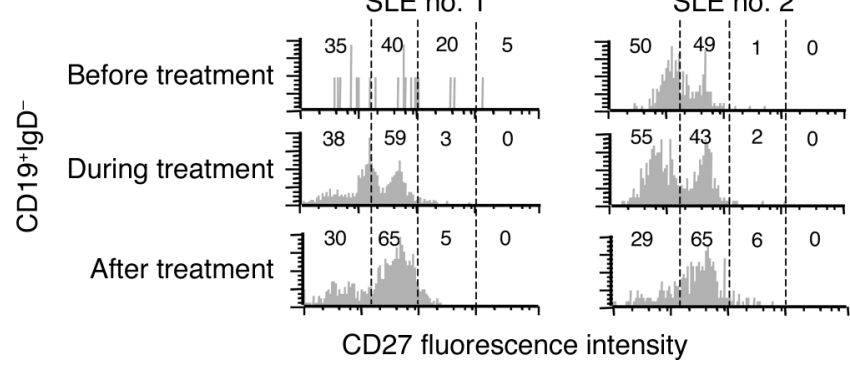

sustained disappearance of Ig-secreting cells from the peripheral blood for the duration of the treatment regimen. Two months after withdrawal of treatment with humanized anti-CD154 mAb, the Ig-secreting cells reappeared in the peripheral blood (Figure $7 \mathrm{~b}$ ).

Treatment of active-SLE patients with humanized antiCD154 mAb (BG9588, 5c8) decreases anti-dsDNA Ab levels, decreases the degree of proteinuria, and improves the SLE disease activity index score. The overall clinical response observed in the multicenter trial has been reported (40). All four patients included in this analysis showed some improvement during and after the treatment period with humanized anti-CD154 mAb (BG9588, $5 c 8$ ) (Figure 8). A treatment-related decrease in anti$\mathrm{dsDNA} A \mathrm{~b}$ was seen in all patients. The pretreatment level of serum anti-dsDNA Ab was $188.5 \pm 355 \mathrm{IU} / \mathrm{ml}$ (100\%; range 9.4-981 $\mathrm{IU} / \mathrm{ml}$, normal value $<3.6$ $\mathrm{IU} / \mathrm{ml}$ ). After two treatments, serum anti-dsDNA significantly decreased to $64 \% \pm 19 \%$ of the pretreatment value (range $32-81 \% ; P=0.008$ ). In the three patients who received more than three treatments, a significant decrease in serum anti-dsDNA Ab was observed after three and four treatments ( 2 and 3 months), to $66 \% \pm 2 \%$ (range $63-68 \% ; P=0.001$ ) and $63 \% \pm 7 \%$ (range 54-69\%; $P=0.0001$ ) of the pretreatment value, respectively. Six months after treatment was withdrawn, serum anti-dsDNA Ab rebounded to $113 \% \pm 33 \%$ (range 67-157\%) of the pretreatment level. Gradual increases started at 2 months after treatment, to $61 \%$ $\pm 30 \%$ (range $26-105 \%$ ) of pretreatment levels, and continued 3 months after treatment to $80 \% \pm 25 \%$ (range 60-122\%) of pretreatment levels.
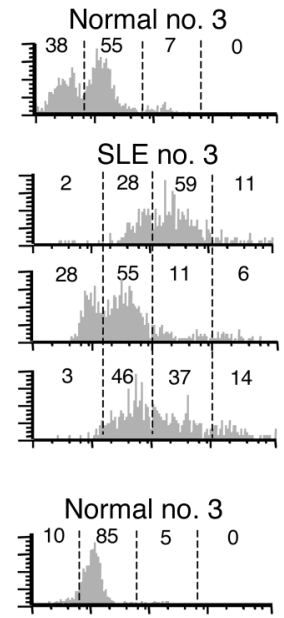

SLE no. 3

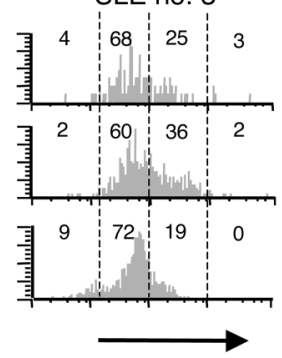

Figure 5

Impact of treatment with humanized anti-CD154 Ab (5c8) on CD27-expressing B cell subsets. Freshly isolated PBMCs from active-SLE patients and normal volunteers were assessed for CD27 expression in B cell subsets by FACS analysis following staining with FITC-conjugated anti-CD27, PE-conjugated anti-IgD, and TC-conjugated anti-CD19. Histograms of CD27 expression on $\mathrm{B}$ cells from normal volunteers or active-SLE patients before treatment, during treatment (SLE nos. 1 and 2, 2 months; SLE no. 3, 1 month), or after withdrawal of treatment (SLE no. 1, 3 months after; SLE no. 2, 20 months after; SLE no. 3, 2 months after) are shown

The mean proteinuria for all four patients enrolled in the anti-CD 154 trial was $3.6 \pm 1.4 \mathrm{~g} / 24 \mathrm{~h}(100 \%$; normal value $0 \mathrm{~g} / 24 \mathrm{~h}$ ) at the pretreatment time point. Following two treatments, proteinuria was $94 \% \pm 9 \%$ of the pretreatment level $(3.4 \pm 1.5 \mathrm{~g} / 24 \mathrm{~h} ; P>0.05)$. Proteinuria was significantly decreased from the pretreatment value following three treatments at the 2 -month time point $(2.5 \pm 1.8 \mathrm{~g} / 24 \mathrm{~h}, 68 \% \pm 35 \%$ of the pretreatment level; $P<0.05)$. This significant decrease was sustained at the 3 -month time point (four treatments, $2.1 \pm 1.1 \mathrm{~g} / 24 \mathrm{~h}, 60 \% \pm 21 \%$ of the pretreatment level) and in the post-treatment period ( 3 months, 1.9 $\pm 1.5 \mathrm{~g} / 24 \mathrm{~h}, 65 \% \pm 31 \%$ of the pretreatment level; 6 months, $1.6 \pm 1.9 \mathrm{~g} / 24 \mathrm{~h}, 48 \% \pm 41 \%$ of the pretreatment level; $P<0.05)$. A long-term effect of anti-CD154 treatment on kidney function was suggested by the finding that at the 20 -month post-treatment time point, mean proteinuria was $0.6 \pm 0.6 \mathrm{~g} / 24 \mathrm{~h}(32 \% \pm$ $31 \%$ of the pretreatment level) in three of four patients with a prolonged response.

SLE disease activity index (SLEDAI) was measured at a pretreatment time point, during the course of treatment, and after treatment was withdrawn. The mean SLEDAI for all four patients enrolled in the anti-CD154 trial was $10.6 \pm 3.9(100 \%)$ at the pretreatment time point, $7.3 \pm 4.7(71 \% \pm 42 \%)$ after two treatments, and $4.0 \pm 1.6(42 \% \pm 12 \%$ of the pretreatment score; $P<0.05)$ at the 2 -month time point after three treatments. This favorable effect of anti-CD154 treatment on SLEDAI was persistent after cessation of treatment, as the mean SLEDAI recorded 3 months after the final treatment was $5.6 \pm 3.7(52 \% \pm 30 \%$ of 


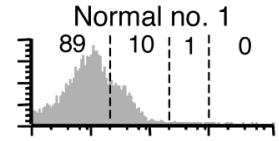

SLE no. 1

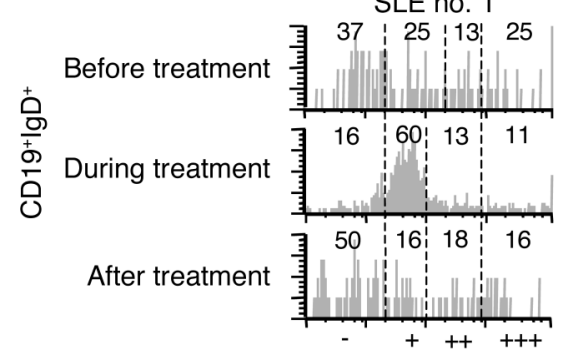

Normal no. 1

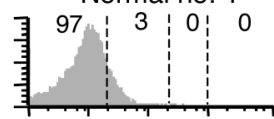

SLE no. 1

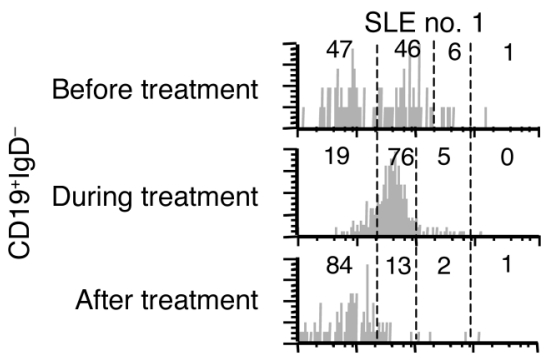

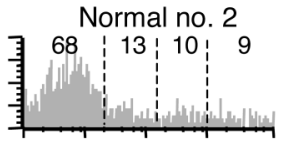

SLE no. 2

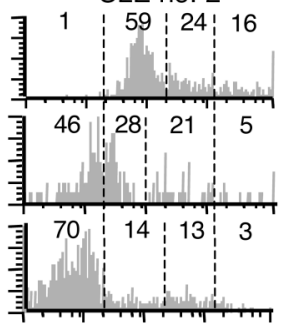

Normal no. 2

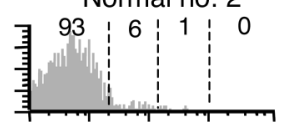

SLE no. 2

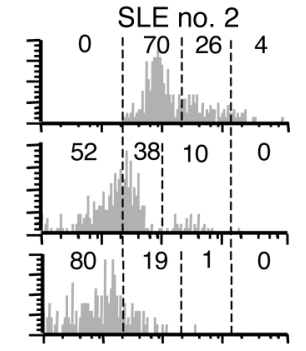

CD5 fluorescence intensity
Normal no. 3

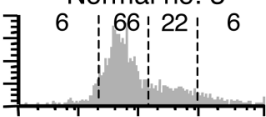

SLE no. 3

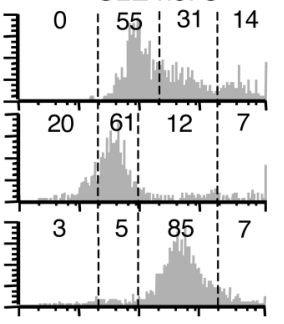

Normal no. 3

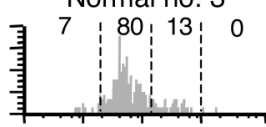

SLE no. 3

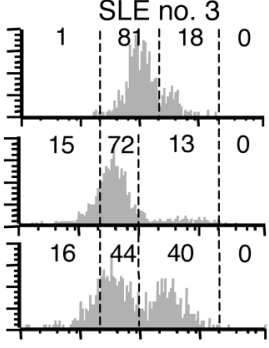

Figure 6

CD5 subsets of peripheral B cells diminish following treatment with humanized anti-CD154 Ab (h5c8). Freshly isolated PBMCs from active-SLE patients and normal volunteers were assessed for CD5 expression in B cell subsets by FACS analysis following staining with FITC-conjugated anti-lgD, PE-conjugated anti-CD19, and TCconjugated anti-CD5. Histograms of CD5 expression on B cells from normal volunteers or active-SLE patients before treatment, during treatment (SLE nos. 1 and 2, 2 months; SLE no. 3, 1 month), or after withdrawal of treatment (SLE no. 1, 3 months after; SLE no. 2, 20 months after; SLE no. 3, 2 months after) are shown. the pretreatment score; $P<0.05)$. Moreover, in the three patients (SLE nos. 1, 2, and 4) examined 20 months after the final treatment, the mean SLEDAI was $2.7 \pm 2.5(17 \% \pm 14 \%)$, compared with a mean score of $12.7 \pm 4.1$ in these patients before treatment $(P<0.05)$. The major determinants of the improvement in SLEDAI were proteinuria, changes in antidsDNA $\mathrm{Ab}$, and improvement in urinary-sediment and complement levels. Notably, all clinical improvements occurred in the setting of a lowered daily dose of prednisone from a median of $22.5 \mathrm{mg} / \mathrm{d}$ (range $5-30 \mathrm{mg} / \mathrm{d}$ ) at base line to a median of $12.5 \mathrm{mg} / \mathrm{d}$ (range $3.75-20 \mathrm{mg} / \mathrm{d}$ ) at 1 month post-treatment.

The clinical course of the four active-SLE patients treated with humanized anti-CD154 mAb (BG9588, $5 c 8)$ showed two different patterns following treatment withdrawal. SLE nos. 1 and 2 continued to improve in all aspects of their disease with the exception of a temporary increase in anti-dsDNA Ab levels in SLE no. 1 at 6 months after treatment was withdrawn. Importantly, SLE nos. 1 and 2 achieved and maintained complete renal remission without any additional clinical intervention following treatment withdrawal. SLE nos. 3 and 4 exhibited a different pattern. Although both SLE nos. 3 and 4 improved during treatment with humanized anti-CD154 mAb (BG9588, 5c8) and immediately following treatment withdrawal, they eventually exhibited disease reactivation and required additional immunosuppressive therapy.

\section{Discussion}

Although the results reported here were derived from an uncontrolled open-label study involving a small number of patients, the data suggest a central role of CD154CD40 interactions in SLE, since specifically blocking this receptor-ligand pair in vivo significantly reduced serum autoantibodies, proteinuria, and an index of disease activity, SLEDAI. Importantly, anti-CD154 treatment decreased circulating CD38 bright, Ig-secreting cells in a time course that was generally similar to that of the reduction of serum anti-dsDNA $\mathrm{Ab}$. These results were similar to the loss of Ig- and anti-DNA-secreting cells, as detected by ELISpot, that was previously reported following treatment of SLE patients with the humanized anti-CD154 BG9588 $\mathrm{mAb}(40)$. In addition, blocking the CD154-CD40 pair during in vitro cultures of highly purified $B$ cells or during in vivo treatment of active-SLE patients reduced spontaneous B cell proliferation as well as the presence of $\mathrm{CD} 38^{\text {positive }} \mathrm{B}$ cells $\left(\mathrm{CD}^{2} 8^{+/++} \mathrm{IgD}^{+}\right.$or $\left.\mathrm{CD}^{+} 8^{+} \mathrm{IgD}^{-}\right)$, which have previously been described in both tonsil tissue from non-autoimmune healthy controls (5) and SLE patients (22) as intermediates in the pathway to Ig-secreting cell development. Moreover, treatment with anti-CD154 decreased the appearance of pre-switch $\mathrm{IgD}^{+} \mathrm{B}$ cells that were bright for CD5 or CD27 in the periphery with a time course similar to that of the disappearance of $\mathrm{CD}_{38} 8^{+/+}$Ig-secreting cell differentiation intermediates or Ig-secreting cells. Finally, B cells that spontaneously expressed CD5 or CD27 at a low 
a

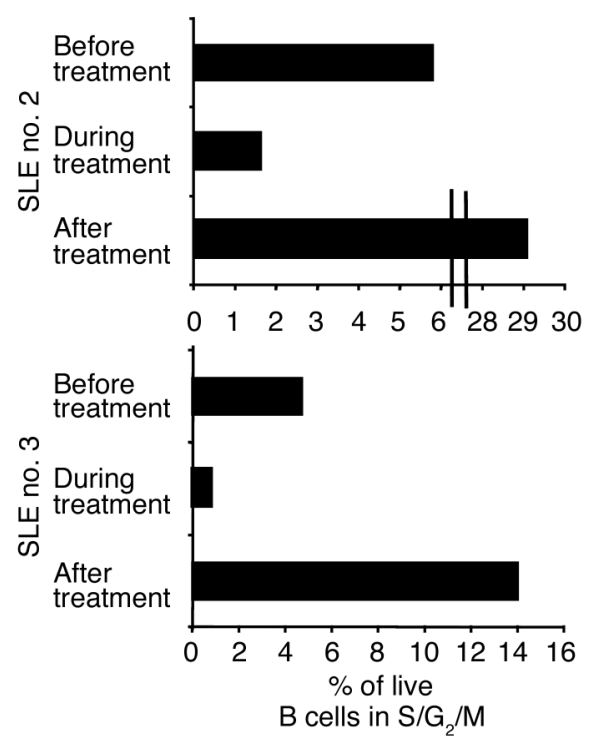

b

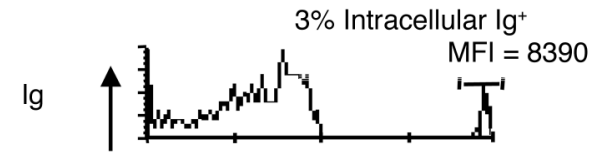

Cell
cycle
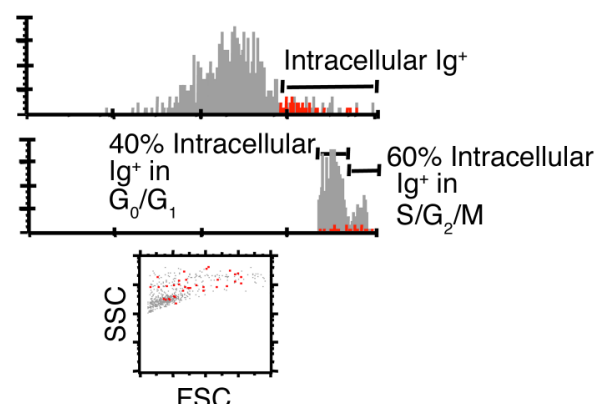

FSC

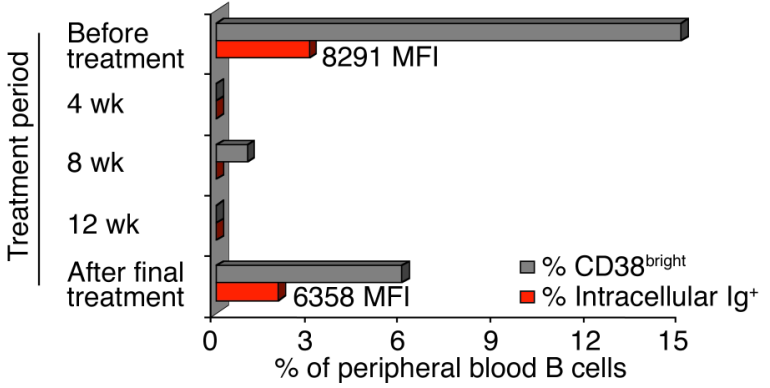

Figure 7

Anti-CD154 treatment eliminates proliferating B cells and Ig-secreting B cells from the periphery of active-SLE patients. (a) Freshly isolated PBMCs from active-SLE patients before treatment, after two treatments, and 2-3 months after the final treatment were assessed for cell cycle following permeabilization, fixation, and staining with propidium iodide and APC-conjugated anti-CD19 Ab. The percentages of live cells in the $S, G_{2}$, or M stage are depicted. (b) Freshly isolated PBMCs from SLE no. 3 before treatment, after two treatments, and 3 months after the final treatment were assessed for intracellular Ig and cell cycle following permeabilization, fixation, and staining with propidium iodide and FITC-conjugated anti-Ig and APC-conjugated anti-CD19 Ab. The presence of IC Ig, the expression of CD38, and cell cycle status are depicted. The percentage of $\mathrm{IC} \mathrm{Ig}^{+} \mathrm{B}$ cells was determined by subtraction of the histogram generated for nonpermeabilized cells (surface Ig-positive) from the one generated for permeabilized cells (surface and IC Ig-positive) using CellQuest. The percentages of live cells that are CD38 bright or IC $\mathrm{Ig}^{+}$are depicted. SSC, side scatter; FSC, forward scatter.

level, or the early-activation antigens CD69 and CD154, disappeared from the periphery of SLE patients during the post-treatment period. Together, these results suggest that spontaneous CD154-CD40 interactions in active-SLE patients drive $B$ cell activation, proliferation, and differentiation to autoantibody-secreting plasma cells that mediate proteinuria and disease activity. Since CD154-CD40 interactions are essential for the development of GC reactions (11), and the Ig-secreting cells found in active-SLE patients have the mutational patterns characteristic of plasma cells generated during GC reactions (42-46), the data are consistent with the conclusion that GC reactions play a central role in the systemic B cell overactivity that is characteristic of SLE.

Previous studies have defined B cell subsets from inflamed secondary lymphoid tissue such as tonsil (5, 15-19) or the periphery of active-SLE patients (22-26) by expression of IgD and CD38. Of note, the current results confirm published studies that have demonstrated that $\mathrm{B}$ cells in the periphery of active-SLE patients express significantly higher levels of $\mathrm{CD} 38$ than $\mathrm{B}$ cells in the periphery of normal, non-autoimmune individuals $(22,25,26)$. In tonsil, pre-switch $\mathrm{IgD}^{+} \mathrm{CD} 38^{+/++}$cells have been defined as activated naive, follicular, mantle zone, or GC founder cells $(5,15,20,21)$ and, when isolated from inflamed tonsils, spontaneously differentiate to $\mathrm{CD}^{2} 8^{++} \mathrm{IgD}^{+} \mathrm{Ig}$ secreting cells in vitro (data not shown). Post-switch $\mathrm{CD}^{2} 8^{+/++} \mathrm{IgD}^{-} \mathrm{B}$ cells are known as GC cells and, when isolated from inflamed tonsils, spontaneously differentiate in vitro to either $\mathrm{CD}^{2} \mathrm{IgD}^{-}$memory cells (5) or $\mathrm{CD}^{2} 8^{++} \mathrm{IgD}-\mathrm{Ig}$-secreting cells (data not shown). Importantly, $\mathrm{CD} 38^{-/+++} \mathrm{B}$ cells isolated from the periphery of active-SLE patients have been observed to differentiate spontaneously to Ig-secreting cells when cultured in vitro (22), confirming the role of $\mathrm{CD} 38^{-/++++}$cells in the periphery of SLE patients as Ig-secreting differentiation intermediates. Of note, the percentages of $\mathrm{CD} 38^{+/++} \mathrm{IgD}^{+} \mathrm{Ig}$ secreting cell differentiation intermediates and of $\mathrm{CD} 38^{++} \mathrm{IgD}^{+}$Ig-secreting cell populations were significantly greater in the blood of active-SLE patients than in the periphery of normal non-autoimmune volunteers, whereas the percentage of $\mathrm{CD} 38-\mathrm{IgD}{ }^{+}$peripheral $\mathrm{B}$ cells was equivalent in active-SLE patients and normal nonautoimmune volunteers. These data suggest that the presence of $\mathrm{CD}^{2} 8^{+++}$pre-switch $\mathrm{IgD}^{+} \mathrm{B}$ cells in the periphery of SLE patients is associated with active disease. There were no significant differences between normals and active-SLE patients in the post-switch $\mathrm{IgD}^{-}$subsets 


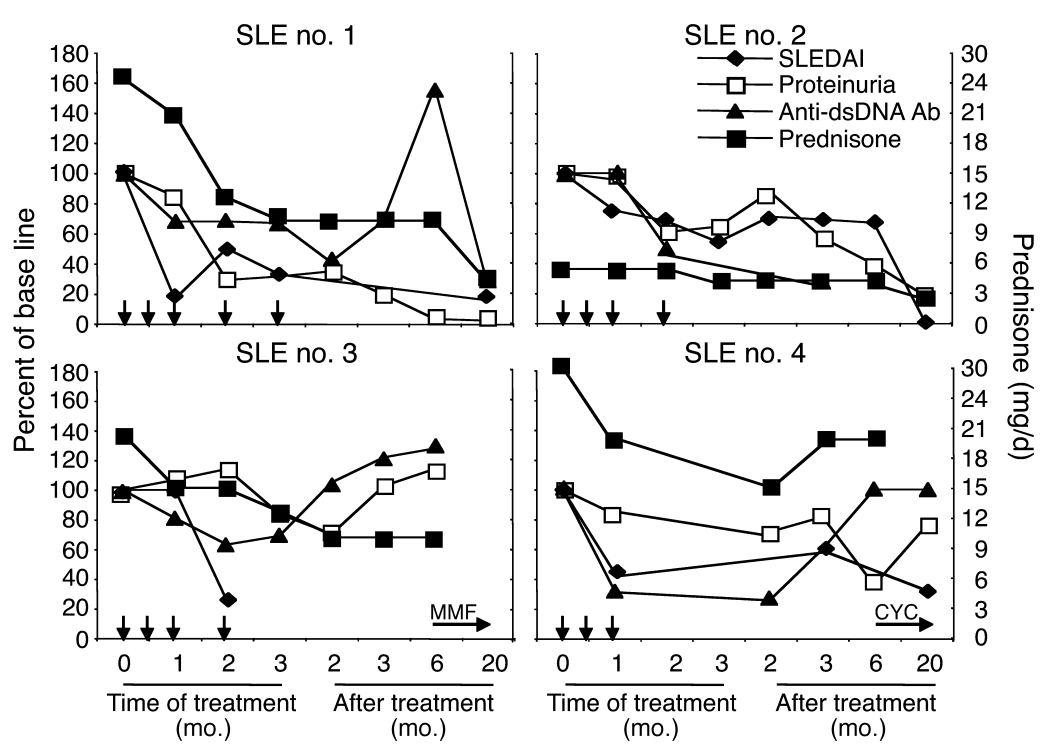

\section{Figure 8}

Treatment of active-SLE patients with humanized anti-CD154 mAb (BG9588, 5c8) decreases antiDNA Ab levels and the degree of proteinuria and improves SLEDAI. Changes in anti-dsDNA Ab levels, 24-hour urinary protein excretion (proteinuria), and SLEDAI are expressed on the left axis as percentage of base-line levels. Prednisone dose is shown on the right axis in $\mathrm{mg} / \mathrm{d}$. Vertical arrows indicate infusions of humanized anti-CD154 mAb (BG9588, 5c8). Horizontal arrows indicate additional immunosuppressive therapy. MMF, mycophenolate mofetil; CYC, cyclophosphamide. defined by CD38. These data extend published observations regarding CD38positive, GC-derived B cells found in the circulation of active-SLE patients by examining the role of CD154-CD40 interactions in their generation and maintenance, especially the $\mathrm{CD} 38^{+++} \mathrm{Ig}$-secreting subsets. It is interesting to speculate whether the Ig-secreting cells in the periphery of active-SLE patients migrate to the kidney, as has been shown for lupus-prone mice (47).

In the present study, evaluation of B cells expressing CD38 in the periphery of active-SLE patients before, during, and after treatment with anti-CD154 mAb extends earlier observations by demonstrating that the $\mathrm{CD} 38^{+/++}$ intermediates in the differentiation path to Ig-secreting cells and CD $38^{+++}$Ig-secreting cells in the periphery of active-SLE patients disappear from the circulation following one to two treatments with anti-CD154 and reappear in the periphery following treatment withdrawal. These results extend previously published data that define $\mathrm{CD} 8^{+/++}$in the periphery of SLE patients as a differentiation intermediate in the path to Ig-secreting cells (22), in that they indicate that the presence of peripheral CD38 ${ }^{+++}$Ig-secreting cell differentiation intermediates and $\mathrm{CD}_{38}{ }^{+++}$Ig-secreting cells in the peripheral blood of active-SLE patients is dependent on CD154-CD40 interactions. Importantly, the upregulation of CD38 expression upon ligation of CD40 on B cells has been demonstrated at both the mRNA (6) and the protein (7) level. The present observations should be considered in light of previous observations indicating that maintenance of follicular/GC reactions requires ongoing signaling through CD154-CD40 interactions. Specifically, entire pre-switch follicles and post-switch GCs rapidly disassemble following administration of an anti-CD154 mAb to an immunized non-autoimmune mouse (30) or lupusprone mouse strains with spontaneous follicular/GC reactions (31, 32). Moreover, blocking CD154-CD40 interactions in vivo abolished antigen-stimulated clonal expansion of B cells in GCs $(33,34)$ and decreased the development of memory B cells $(5,35)$. Furthermore, CD40 ligation preferentially induced differentiation of $\mathrm{CD}^{3} 8^{++} \mathrm{IgD}^{-}$and $\mathrm{CD} 38^{+} \mathrm{IgD}^{-} \mathrm{GC}$ B cells to memory cells defined by phenotype as well as function (36). In conclusion, the abundance of $\mathrm{CD} 38^{+/++}$Ig-secreting cell differentiation intermediates and $\mathrm{CD} 38^{+++} \mathrm{Ig}$-secreting cells in the peripheral blood of active-SLE patients is likely to be dependent on overactive GC reactions that are themselves dependent on the CD154-CD40 ligand-receptor pair. Of note, although the majority of the $\mathrm{IgD}^{-} \mathrm{B}$ cells in the active-SLE patients enrolled in the anti-CD154 Ab trial expressed surface IgM, the isotype of $\mathrm{CD} 38^{+++} \mathrm{IgD}^{-}$plasma cells cannot be determined by surface staining, since plasma cells are largely sIg-

Memory and Ig-secreting B cell subsets have been defined in inflamed secondary lymphoid tissue and in the periphery of active-SLE patients by differential expression of CD27 and CD5. In inflamed secondary lymphoid tissue, memory and Ig-secreting B cell subsets have been identified in the subepithelial regions of tonsil. Of note, memory cells are Ig-secreting cell differentiation intermediates that can be driven to Ig-secreting cells following engagement of CD40 $(37,38) . \mathrm{IC} \mathrm{Ig}^{+} \operatorname{IgM}^{+} \operatorname{IgD}^{+} \mathrm{B}$ cells have been observed to express a higher level of CD27 and CD5 $(13,14,18)$ when compared with $\mathrm{IC}^{-} \operatorname{IgM}^{+} \operatorname{IgD}^{+} \mathrm{B}$ cells that have been defined as memory cells based on the presence of somatic hypermutation of Ig genes (13). Of note, differential CD27 expression has been used to distinguish $\mathrm{IC} \mathrm{Ig}^{+}$cells from IC Ig- memory B cells isolated from the periphery of active-SLE patients $(25,27)$. In addition, somatic hypermutation of $\mathrm{Ig}$ is more extensive in the $\mathrm{IC} \mathrm{Ig}^{+}$population from either tonsil or the periphery of active-SLE patients than in the IC Ig memory population $(13,27)$. By contrast, the CD27-negative population did not show evidence of Ig somatic hypermutation in B cells from tonsil or the periphery of active-SLE patients. Studies using tonsillar B cells have shown that a high level of CD5 marks subepithelial plasmablasts and 
a low level of $\mathrm{CD} 5$ identifies activated pre- or post-switch $\mathrm{B}$ cells in the follicular/GC or extrafollicular/subepithelial regions $(14,19)$. In vitro experiments have demonstrated that $\mathrm{CD} 5$ can be induced on the surface of B cells following stimulation through CD40 (9) or following coculture with anti-CD3-activated T cells (10). Although studies have demonstrated that Ig-secreting cells can be generated from either $\mathrm{CD}^{-}$or CD5positive $\mathrm{B}$ cells (10), plasmablasts that secrete anti-dsDNA Ab express a high level of CD5, and fully differentiated, nonproliferating plasma cells have been observed to be CD5-negative (29, 48). In the current study, the percentage and MFI of CD27 and CD5 expressed on the surface of pre-switch B cells from the periphery of SLE patients were significantly higher than those expressed on peripheral or tonsillar $\mathrm{B}$ cells from non-autoimmune controls. In addition, the dependence of these pre-switch $\mathrm{IgD}^{+}$subsets on ongoing CD154-CD40 interactions was demonstrated by the finding that treatment of active-SLE patients with anti$\mathrm{CD} 154 \mathrm{mAb}$ decreased the percentage of $\mathrm{CD}^{\text {bright }}$, $\mathrm{CD} 27^{\text {bright }}$, and $\mathrm{IC}_{\mathrm{Ig}}^{+} \mathrm{CD} 38^{\text {bright }} \mathrm{B}$ cells in the periphery. These data confirm that CD154-CD40 interactions occurring in active-SLE patients generate Ig-secreting cell differentiation intermediates such as CD27-positive memory cells and Ig-secreting cells that can be identified by a number of markers including high expression of CD38, CD27, and CD5.

In normal individuals as well as autoimmune individuals, targeted somatic hypermutation of Ig has been found in CD27-positive but not CD27-negative preswitch IgD ${ }^{+} \mathrm{B}$ cells $(13,25,27)$. Moreover, histological GCs (49) and a hallmark of GC reactions, targeted RGYW/WRCY somatic hypermutation of heavy and light chain Ig genes, have been demonstrated to be absent in X-linked hyper-IgM patients genetically deficient in CD154 expression $(50,51)$ and thus functional CD154-CD40 interactions. Interestingly, low percentages of $\mathrm{CD}_{27} \mathrm{IgD}^{+}$peripheral $\mathrm{B}$ cells have been reported in X-linked hyper-IgM patients with a complete block of functional CD154-CD40 interactions (the mean of the values from the two reports is $4.4 \% \pm 1.3 \%$, range $1-12 \%$, $n=8)(52,53)$. Of note, the percentage of CD27-positive $\mathrm{IgD}^{+} \mathrm{B}$ cells in the periphery of X-linked hyper-IgM patients is markedly lower $(P<0.05)$ than that found in the periphery of normal non-autoimmune volunteers $(36.2 \% \pm 6.9 \%$; Table 2$)$, which in turn is significantly lower than that found in the active-SLE patients before treatment with humanized anti-CD154 mAb $(97.0 \% \pm 2.1 \%$; Table 2$)$. In light of these observations, signals other than CD154-CD40 interactions may make a minor contribution to the appearance of $\mathrm{CD} 27^{+} \mathrm{IgD}{ }^{+} \mathrm{B}$ cells in the periphery, as has been observed in some circumstances for expression of other activation/differentiation antigens such as CD69, CD154, and CD5 (5, 9, 11). This contribution is most apparent in patients that lack functional CD154-CD40 interactions, such as $\mathrm{X}$-linked hyper-IgM, since the percentage of $\mathrm{CD} 27^{+}$ circulating $\mathrm{IgD}^{+}$peripheral $\mathrm{B}$ cells is small. In normal individuals, however, the vast majority of $\mathrm{CD} 27^{+} \mathrm{IgD}{ }^{+} \mathrm{B}$ cells appear to be pre-switch memory cells that have originated from GCs in secondary lymphoid tissues.

Active-SLE patients have a higher percentage of circulating $B$ cells expressing early-activation antigens such as CD69, CD154, or a low level of CD5 than do nonautoimmune individuals. Treatment of active-SLE patients with anti-CD154 mAb resulted in a decrease in B cells expressing CD69, CD154, or a low level of CD5 during the post-treatment time period. Of note, although ligation of CD40 on highly purified B cells from normal individuals during in vitro culture induced expression of CD5 (9) and CD154 (5), there are other signals that also contribute to increased expression of these early-activation antigens, including cytokines and engagement of sIg (11), and these other signals may lead to continued expression following blockade of CD154CD40 interactions. In this regard, the initial stages of B cell activation have been previously shown to be independent of CD154-CD40 interactions $(54,55)$. The finding that markers of early B cell activation such as CD69 and CD154 continue to be expressed on B cells from the periphery of active-SLE patients after treatment with anti-CD154 mAb suggests that the eventual decrease in these early-activation markers may be secondary to improvement in disease activity of SLE and not a primary effect of blocking CD154-CD40 interactions.

Treatment of active-SLE patients with anti-CD154 $\mathrm{mAb}$ led to a rapid decrease in serum anti-dsDNA autoantibody levels that paralleled the disappearance of $\mathrm{CD} 38^{\text {bright }} \mathrm{IC} \mathrm{Ig}^{+}$plasma cells from the circulation. Of note, Ig-secreting cells producing anti-dsDNA Ab have been previously shown to be dependent on ongoing proliferation, since anti-dsDNA Ab levels, but not levels of other autoantibodies, can be inhibited by treatment with antiproliferative drugs such as cyclophosphamide (56-60). These data confirm in vitro experiments that demonstrated that CD154 expression on B cells leads to homotypic CD154-CD40 interactions that mediate proliferation, Ig secretion, and a positive feedback loop that results in increased CD154 expression on B cells (5, 56-64), as well as in vivo experiments that demonstrated that mice transgenic for CD154 on all cells $(65,66)$, or B cells alone (67), spontaneously developed plasmablasts that secreted pathogenic anti-dsDNA Ab.

In summary, the current data demonstrate that treating active-SLE nephritis patients with an $\mathrm{mAb}$ against CD154 inhibits disease activity as well as abnormal B cell differentiation that leads to the presence of circulating Ig-secreting cells and serum anti-dsDNA Ab (39). Of note, anti-cardiolipin levels, anti-nuclear antigen (ANA) titer, and total serum Ig levels did not change significantly with treatment (data not shown) (40). Flow cytometric analysis of peripheral B cell subsets in active-SLE patients, defined by $\operatorname{IgD}, \mathrm{CD} 38$, cell cycle status, and the presence of IC Ig, demonstrated that the disappearance of Ig-secreting cells in the periphery was associated with decreases in anti-dsDNA Ab levels, proteinuria, and SLEDAI. Together, these observations indicate that in vivo CD154-CD40 interactions drive 
SLE disease activity and aberrations in the peripheral B cell compartment of active-SLE patients.

Although this hypothesis would be stronger following testing in a larger, properly controlled clinical trial, the findings are consistent with published preclinical work and suggest that CD154-CD40 interactions should be a central target of therapy in SLE. Moreover, the association between normalization of $B$ cell subsets and clinical improvements in disease activity, in addition to the complete remission of the two patients treated with the longest course of humanized anti-CD154 mAb, strongly suggests the benefit of further exploring this treatment in active SLE. Since anti-CD154 treatment was associated with an increased frequency of thrombotic events in treated patients, the goal would be to develop a safer means to test the hypothesis generated by these and previous studies. The mechanism of thrombosis is not understood, although CD154-CD40 interactions involving activated platelets (68-73) and endothelial cells (74-89) in persons with underlying vascular disease may play a significant role. The use of another $\mathrm{mAb}$ to CD154 (24-31; IDEC-131) in SLE was apparently not associated with an increased frequency of thrombosis, although minimal efficacy was also noted $(90,91)$. To find a safe and effective means to block CD154-CD40 interactions in active-SLE patients remains a challenge.

\section{Acknowledgments}

The authors would like to thank Iris Pratt for assistance with manuscript preparation, Kristien J.M. Zaal and Evelyn Ralston for microscopic assistance with the cover picture, Bonnie Darnell and Joseph Beckham for technical assistance with the flow cytometric sorting experiments, as well as Dimitrios Boumpas and Mildred Wilson, who respectively organized and coordinated the NIH portion of the BG9588 clincal trial. A.C. Grammer was supported by the Arthritis Foundation. R. Slota is recipient of the NIH Undergraduate Scholar Program and is currently an NIH-UGSP scholar (website: http://ugsp.info.nih.gov).

1. Grammer, A.C., Dorner, T., and Lipsky, P.E. 2001. Abnormalities in B cell activity and the immunoglobulin repertoire in human systemic lupus erythematosus. Molecular Pathology of Autoimmune Diseases. 2:282-318.

2. Lipsky, P.E. 2001. Systemic lupus erythematosus: an autoimmune disease of B cell hyperactivity. Nat. Immunol. 2:764-766.

3. Grammer, A.C., and Lipsky, P.E. 2002. CD154-CD40 interactions mediate differentiation to plasma cells in healthy individuals and persons with systemic lupus erythematosus. Arthritis Rheum. 46:1417-1429.

4. Dorner, T., and Lipsky, P.E. 2001. Immunoglobulin variable-region gene usage in systemic autoimmune diseases. Arthritis Rheum. 44:2715-2727.

5. Grammer, A.C., McFarland, R.D., Heaney, J., Darnell, B.F., and Lipsky, P.E. 1999. Expression, regulation, and function of B cell-expressed CD154 in germinal centers. J. Immunol. 163:4150-4159.

6. Dadgostar, H., et al. 2002. Cooperation of multiple signaling pathways in CD40-regulated gene expression in B lymphocytes. Proc. Natl. Acad. Sci. U. S. A. 99:1497-1502.

7. Miyashita, T., et al. 1997. Bidirectional regulation of human B cell responses by $\mathrm{CD} 40-\mathrm{CD} 40$ ligand interactions. J. Immunol. 158:4620-4633.

8. Gagro, A., et al. 2003. Naive and memory B cells respond differentially to T-dependent signaling but display an equal potential for differentiation toward the centroblast-restricted CD77/globotriaosylceramide phenotype. Eur. J. Immunol. 33:1889-1898.

9. Gagro, A., et al. 2000. CD5-positive and CD5-negative human B cells converge to an indistinguishable population on signalling through B-cell receptors and CD40. Immunology. 101:201-209.

10. Vernino, L.A., Pisetsky, D.S., and Lipsky, P.E. 1992. Analysis of the expression of CD5 by human B cells and correlation with functional activity. Cell. Immunol. 139:185-197.

11. Grammer, A.C., and Lipsky, P.E. 2000. CD40-mediated regulation of immune responses by TRAF-dependent and TRAF-independent signaling mechanisms. Adv. Immunol. 76:61-178.

12. Falini, B., et al. 2003. Expression of the IRTA1 receptor identifies intraepithelial and sub-epithelial marginal zone B cells of the mucosa-associated lymphoid tissue (MALT). Blood. Jul 24. Online publication ahead of print.

13. Dono, M., et al. 2000. Heterogeneity of tonsillar subepithelial B lymphocytes, the splenic marginal zone equivalents. J. Immunol. 164:5596-5604

14. Su, W., Yeong, K.F., and Spencer, J. 2000. Immunohistochemical analysis of human CD5 positive B cells: mantle cells and mantle cell lymphoma are not equivalent in terms of CD5 expression. J. Clin. Pathol. 53:395-397.

15. Liu, Y.J., and Arpin, C. 1997. Germinal center development. Immunol. Rev. 156:111-126.

16. Choi, Y.S. 1997. Differentiation and apoptosis of human germinal center B-lymphocytes. Immunol. Res. 16:161-174.

17. Mattila, P.S., and Tarkkanen, J. 1997. Age-associated changes in the cellular composition of the human adenoid. Scand. J. Immunol. 45:423-427.

18. Dono, M., et al. 1996. Subepithelial B cells in the human palatine tonsil. I. Morphologic, cytochemical, and phenotypic characterization. Eur. J. Immunol. 26:2035-2042.

19. Medina, F., Segundo, C., Campos-Caro, A., Gonzalez-Garcia, I., and Brieva, J.A. 2002. The heterogeneity shown by human plasma cells from tonsil, blood, and bone marrow reveals graded stages of increasing maturity, but local profiles of adhesion molecule expression. Blood. 99:2154-2161.

20. Billian, G., Bella, C., Mondiere, P., and Defrance, T. 1996. Identification of a tonsil IgD+ B cell subset with phenotypical characteristics of germinal center B cells. Eur. J. Immunol. 26:1712-1719.

21. Pascual, V., et al. 1994. Analysis of somatic mutation in five B cell subsets of human tonsil. J. Exp. Med. 180:329-339.

22. Harada, Y., et al. 1996. Identification of early plasma cells in peripheral blood and their clinical significance. Br. J. Haematol. 92:184-191.

23. Bourne, T., Zukowska-Cooper, M., Salaman, M.R., Seifert, M.H., and Isenberg, D.A. 1998. Spontaneous immunoglobulin-producing capacity of cultures from lupus patients and normal donors following depletion of cells expressing CD19 or CD38. Clin. Exp. Immunol. 111:611-616.

24. Koarada, S., et al. 1999. B cells lacking RP105, a novel B cell antigen, in systemic lupus erythematosus. Arthritis Rheum. 42:2593-2600.

25. Arce, E., et al. 2001. Increased frequency of pre-germinal center B cells and plasma cell precursors in the blood of children with systemic lupus erythematosus. J. Immunol. 167:2361-2369.

26. Bijl, M., Horst, G., Limburg, P.C., and Kallenberg, C.G. 2001. Fas expression on peripheral blood lymphocytes in systemic lupus erythematosus (SLE): relation to lymphocyte activation and disease activity. Lupus. 10:866-872.

27. Odendahl, M., et al. 2000. Disturbed peripheral B lymphocyte homeostasis in systemic lupus erythematosus. J. Immunol. 165:5970-5979.

28. Jacobi, A.M., et al. 2003. Correlation between circulating CD27high plasma cells and disease activity in patients with systemic lupus erythematosus. Arthritis Rheum. 48:1332-1342.

29. Warrington, R.J., Wong, S.K., Ramdahin, S., and Rutherford, W.J. 1995 Normal human cord blood B cells can produce high affinity IgG antibodies to dsDNA that are recognized by cord blood-derived anti-idiotypic antibodies. Scand. J. Immunol. 42:397-406.

30. Han, S., et al. 1995. Cellular interactions in germinal centers: roles of CD40 ligand and B7-2 in established germinal centers. J. Immunol. 155:556-567.

31. Qian, J., et al. 2000. Role of CD154 in the secondary immune response: the reduction of pre-existing splenic germinal centers and anti-factor VIII inhibitor titer. Eur. J. Immunol. 30:2548-2554.

32. Luzina, I.G., et al. 2001. Spontaneous formation of germinal centers in autoimmune mice. J. Lenkoc. Biol. 70:578-584.

33. Vora, K.A., Tumas-Brundage, K.M., and Manser, T. 1998. A periarteriolar lymphoid sheath-associated B cell focus response is not observed during the development of the anti-arsenate germinal center reaction. J. Immunol. 160:728-733.

34. Garside, P., et al. 1998. Visualization of specific B and T lymphocyte interactions in the lymph node. Science. 281:96-99.

35. Gray, D., Dullforce, P., and Jainandunsing, S. 1994. Memory B cell development but not germinal center formation is impaired by in vivo blockade of CD40-CD40 ligand interaction. J. Exp. Med. 180:141-155.

36. Arpin, C., et al. 1995. Generation of memory B cells and plasma cells in vitro. Science. 268:720-722.

37. Dono, M., et al. 2001. In vitro stimulation of human tonsillar subepithelial B cells: requirement for interaction with activated T cells. Eur.J. Immunol. 31:752-756.

38. Vinuesa, C.G., et al. 2001. Tracking the response of Xid B cells in vivo: TI2 antigen induces migration and proliferation but Btk is essential for terminal differentiation. Eur. J. Immunol. 31:1340-1350.

39. Huang, W., et al. 2002. The effect of anti-CD40 ligand antibody on 
B cells in human systemic lupus erythematosus. Arthritis Rheum. 46:1554-1562

40. Boumpas, D.T., et al. 2003. A short course of BG9588 (anti-CD40L antibody) improves serologic activity and decreases hematuria in patients with proliferative lupus glomerulonephritis. Arthritis Rheum. 48:719-727.

41. Tan, E.M., et al. 1982. The 1982 revised criteria for the classification of systemic lupus erythematosus. Arthritis Rheum. 25:1271-1277.

42. Yavuz, S., Grammer, A.C., Yavuz, A.S., Nanki, T., and Lipsky, P.E. 2001 Comparative characteristics of mu chain and alpha chain transcripts expressed by individual tonsil plasma cells. Mol. Immunol. 38:19-34.

43. Dörner, T., Foster, S.J., Farner, N.L., and Lipsky, P.E. 1998. Immunoglobulin kappa chain receptor editing in systemic lupus erythematosus. J. Clin. Invest. 102:688-694.

44. Dorner, T., Heimbacher, C., Farner, N.L., and Lipsky, P.E. 1999 Enhanced mutational activity of Vkappa gene rearrangements in systemic lupus erythematosus. Clin. Immunol. 92:188-196.

45. Jacobi, A.M., Hansen, A., Burmester, G.R., Dorner, T., and Lipsky, P.E. 2000. Enhanced mutational activity and disturbed selection of mutations in $\mathrm{V}(\mathrm{H})$ gene rearrangements in a patient with systemic lupus erythematosus. Autoimmunity. 33:61-76.

46. Dorner, T., Kaschner, S., Hansen, A., Pruss, A., and Lipsky, P.E. 2001. Perturbations in the impact of mutational activity on Vlambda genes in systemic lupus erythematosus. Arthritis Res. 3:368-374.

47. Cassese, G., et al. 2001. Inflamed kidneys of NZB / W mice are a major site for the homeostasis of plasma cells. Eur. J. Immunol. 31:2726-2732.

48. Suzuki, N., Sakane, T., and Engleman, E.G. 1990. Anti-DNA antibody production by CD5+ and CD5- B cells of patients with systemic lupus erythematosus. J. Clin. Invest. 85:238-247.

49. Facchetti, F., Appiani, C., Salvi, L., Levy, J., and Notarangelo, L.D. 1995. Immunohistologic analysis of ineffective CD40-CD40 ligand interaction in lymphoid tissues from patients with X-linked immunodeficiency with hyper-IgM. J. Immunol. 154:6624-6633.

50. Brezinschek, H.P., Dorner, T., Monson, N.L., Brezinschek, R.I., and Lipsky, P.E. 2000. The influence of CD40-CD154 interactions on the expressed human $\mathrm{V}(\mathrm{H})$ repertoire: analysis of $\mathrm{V}(\mathrm{H})$ genes expressed by individual B cells of a patient with X-linked hyper-IgM syndrome. Int. Immunol. 12:767-775.

51. Monson, N.L., et al. 2001. The role of CD40-CD40 ligand (CD154) interactions in immunoglobulin light chain repertoire generation and somatic mutation. Clin. Immunol. 100:71-81.

52. Agematsu, K., et al. 1998. Absence of IgD-CD27(+) memory B cell population in X-linked hyper-IgM syndrome. J. Clin. Invest. 102:853-860.

53. Weller, S., et al. 2001. CD40-CD40L independent Ig gene hypermutation suggests a second B cell diversification pathway in humans. Proc. Natl. Acad. Sci. U. S. A. 98:1166-1170.

54. Splawski, J.G., and Lipsky, P.E. 1993. CD40-mediated regulation of human B-cell responses. Res. Immunol. 145:226-237.

55. Nishioka, Y., and Lipsky, P.E. 1994. The role of CD40-CD40 ligand interaction in human T cell-B cell collaboration. J. Immunol. 153:1027-1036.

56. McCarty, G.A., Rice, J.R., Bembe, M.L., and Pisetsky, D.S. 1982. Independent expression of autoantibodies in systemic lupus erythematosus. J. Rheumatol. 9:691-695.

57. Perez, M.C., Wilson, W.A., and Scopelitis, E. 1989. Cyclophosphamide use in a young woman with antiphospholipid antibodies and recurrent cerebrovascular accident. South. Med. J. 82:1421-1424.

58. Ginsburg, W.W., Finkelman, F.D., and Lipsky, P.E. 1978. Circulating and mitogen-induced immunoglobulin-secreting cells in human peripheral blood: evaluation by a modified reverse hemolytic plaque assay. J. Immunol. 120:33-39.

59. Jelinek, D.F., and Lipsky, P.E. 1983. The role of B cell proliferation in the generation of immunoglobulin-secreting cells in man. J. Immunol. 130:2597-2604.

60. Vernino, L., McAnally, L.M., Ramberg, J., and Lipsky, P.E. 1992. Generation of nondividing high rate Ig-secreting plasma cells in cultures of human B cells stimulated anti-CD3-activated T cells. J. Immunol. 148:404-410.

61. Grammer, A.C., et al. 1995. The CD40 ligand expressed by human B cells costimulates B cell responses. J. Immunol. 154:4996-5010.

62. Lipsky, P.E., Attrep, J.F., Grammer, A.C., McIlraith, M.J., and Nishoka, Y. 1997. Analysis of CD40-CD40 ligand interactions in the regulation of human B cell function. Ann. N. Y. Acad. Sci. 815:372-383.

63. Shinozaki, K., Yasui, K., and Agematsu, K. 2001. Direct B/B-cell interactions in immunoglobulin synthesis. Clin. Exp. Immunol. 124:386-391.

64. Brams, P., et al. 2001. A humanized anti-human CD154 monoclonal antibody blocks CD154-CD40 mediated human B cell activation. Int. Immunopharmacol. 1:277-294.

65. Lettesjo, H., Burd, G.P., and Mageed, R.A. 2000. CD4+ T lymphocytes with constitutive CD40 ligand in preautoimmune (NZB $\times$ NZW)F1 lupus-prone mice: phenotype and possible role in autoreactivity. J. Immunol. 165:4095-4104.

66. Santos-Argumedo, L., Alvarez-Maya, I., Romero-Ramirez, H., and FloresRomo, L. 2001. Enforced and prolonged CD40 ligand expression triggers autoantibody production in vivo. Eur. J. Immunol. 31:3484-3492.
67. Higuchi, T., et al. 2002. Ectopic expression of CD40 ligand on B cells induces lupus-like autoimmune disease. J. Immunol. 168:9-12.

68. Krzysiek, R., et al. 2000. Regulation of CCR6 chemokine receptor expression and responsiveness to macrophage inflammatory protein3alpha/CCL20 in human B cells. Blood. 96:2338-2345.

69. Henn, V., Steinbach, S., Buchner, K., Presek, P., and Kroczek, R.A. 2001. The inflammatory action of CD40 ligand (CD154) expressed on activated human platelets is temporally limited by coexpressed CD 40 . Blood. 98:1047-1054

70. Hermann, A., Rauch, B.H., Braun, M., Schror, K., and Weber, A.A. 2001. Platelet CD40 ligand (CD40L): subcellular localization, regulation of expression, and inhibition by clopidogrel. Platelets. 12:74-82.

71. Schwarz, U.R., Kobsar, A.L., Koksch, M., Walter, U., and Eigenthaler, M. 2000 . Inhibition of agonist-induced p42 and p38 mitogen-activated protein kinase phosphorylation and CD40 ligand/P-selectin expression by cyclic nucleotide-regulated pathways in human platelets. Biochem. Pharmacol. 60:1399-1407.

72. Slupsky, J.R., et al. 1998. Activated platelets induce tissue factor expression on human umbilical vein endothelial cells by ligation of CD40. Thromb. Haemost. 80:1008-1014.

73. Henn, V., et al. 1998. CD40 ligand on activated platelets triggers an inflammatory reaction of endothelial cells. Nature. 391:591-594.

74. Schonbeck, U., and Libby, P. 2001. CD40 signaling and plaque instability. Circ. Res. 89:1092-1103.

75. Bruemmer, D., et al. 2001. Expression of CD40 in vascular smooth muscle cells and macrophages is associated with early development of human atherosclerotic lesions. Am. J. Cardiol. 87:21-27.

76. Hakkinen, T., Karkola, K., and Yla-Herttuala, S. 2000. Macrophages, smooth muscle cells, endothelial cells, and T-cells express CD40 and CD40L in fatty streaks and more advanced human atherosclerotic lesions. Colocalization with epitopes of oxidized low-density lipoprotein, scavenger receptor, and CD16 (Fc gammaRIII). Virchows Arch. 437:396-405.

77. Lienenluke, B., Germann, T., Kroczek, R.A., and Hecker, M. 2000. CD154 stimulation of interleukin-12 synthesis in human endothelial cells. Eur. J. Immunol. 30:2864-2870

78. Kotowicz, K., Dixon, G.L., Klein, N.J., Peters, M.J., and Callard, R.E. 2000. Biological function of CD40 on human endothelial cells: costimulation with CD40 ligand and interleukin-4 selectively induces expression of vascular cell adhesion molecule-1 and P-selectin resulting in preferential adhesion of lymphocytes. Immunology. 100:441-448.

79. Thienel, U., Loike, J., and Yellin, M.J. 1999. CD154 (CD40L) induces human endothelial cell chemokine production and migration of leukocyte subsets. Cell. Immunol. 198:87-95.

80. Jollow, K.C., Zimring, J.C., Sundstrom, J.B., and Ansari, A.A. 1999. CD40 ligation induced phenotypic and functional expression of CD80 by human cardiac microvascular endothelial cells. Transplantation. 68:430-439.

81. Schonbeck, U., et al. 1999. Expression of stromelysin-3 in atherosclerotic lesions: regulation via CD40-CD40 ligand signaling in vitro and in vivo. J. Exp. Med. 189:843-853.

82. Slupsky, J.R., et al. 1998. Activated platelets induce tissue factor expression on human umbilical vein endothelial cells by ligation of CD40. Thromb. Haemost. 80:1008-1014.

83. Zhou, L., et al. 1998. CD40 engagement on endothelial cells promotes tissue factor-dependent procoagulant activity. Thromb. Haemost. 79:1025-1028.

84. Dechanet, J., et al. 1997. CD40 ligand stimulates proinflammatory cytokine production by human endothelial cells. J. Immunol. 159:5640-5647.

85. Miller, D.L., Yaron, R., and Yellin, M.J. 1998. CD40L-CD40 interactions regulate endothelial cell surface tissue factor and thrombomodulin expression. J. Leukoc. Biol. 63:373-379.

86. Mach, F., et al. 1997. Functional CD40 ligand is expressed on human vascular endothelial cells, smooth muscle cells, and macrophages: implications for CD40-CD40 ligand signaling in atherosclerosis. Proc. Natl. Acad. Sci. U. S. A. 94:1931-1936.

87. Karmann, K., Min, W., Fanslow, W.C., and Pober, J.S. 1996. Activation and homologous desensitization of human endothelial cells by CD40 ligand, tumor necrosis factor, and interleukin 1. J. Exp. Med. 184:173-182.

88. Hollenbaugh, D., et al. 1995. Expression of functional CD40 by vascular endothelial cells. J. Exp. Med. 182:33-40.

89. Karmann, K., Hughes, C.C., Schechner, J., Fanslow, W.C., and Pober, J.S. 1995. CD40 on human endothelial cells: inducibility by cytokines and functional regulation of adhesion molecule expression. Proc. Natl. Acad. Sci. U. S. A. 92:4342-4346.

90. Davis, J.C., Jr., Totoritis, M.C., Rosenberg, J., Sklenar, T.A., and Wofsy, D. 2001. Phase I clinical trial of a monoclonal antibody against CD40-ligand (IDEC-131) in patients with systemic lupus erythematosus. J. Rheumatol. 28:95-101.

91. Kalunian, K.C., et al. 2002. Treatment of systemic lupus erythematosus by inhibition of $\mathrm{T}$ cell costimulation with anti-CD154: a randomized, double-blind, placebo-controlled trial. Arthritis Rheum. 46:3251-3258. 